\title{
Avoidable "Fraccident": An Argument Against Strict Liability for Hydraulic Fracturing"
}

\section{INTRODUCTION}

Hydraulic fracturing, also known as "fracking," recently has grabbed the attention of headlines, ${ }^{1}$ filmmakers, ${ }^{2}$ and even late night comedians. ${ }^{3}$ The reason is a revolution in unconventional "shale gas" drilling. ${ }^{4}$ Shale gas is natural gas trapped in deep, impermeable shale rock formations; fracking is essential to its cost-effective production. ${ }^{5}$ The United States increasingly relies on these unconventional sources of natural gas for its energy needs. ${ }^{6}$ Therefore, the United States increasingly relies on fracking.

* Joe Schremmer. J.D. candidate 2013, University of Kansas School of Law, M.B.A candidate 2013, University of Kansas School of Business; B.A. B.S. 2009, University of Kansas. I would like to thank Professor John Peck for his constructive critique of the Comment, and the entire University of Kansas Law Review board and staff, in particular Colin Baumchen, Lauren Douville, Joel Griffiths, and Jill Moenius. Thanks also to my dad, the Dickster, for all his fracking guidance; to my mom for always worrying; and to my brother and sister for my middle-child complex. I reserve very special thanks for Uncle Jimmy Green, and every other KU Law professor, who made this hill on the Kaw a singular place to learn the law.

1. See, e.g., Mike Soraghan, Baffled About Fracking? You're Not Alone, N.Y. TIMES, May 13, 2011, http://www.nytimes.com/gwire/2011/05/13/13greenwire-baffled-about-fracking-youre-notalone-44383.html?pagewanted=1\&sq=fracking\&st $=\operatorname{cse} \& s c p=2$ (discussing the recent controversy and media coverage of hydraulic fracturing).

2. See, e.g., GASLAND (New Video Group 2010).

3. See, e.g., The Colbert Report: Anti-Frack Attacks (Comedy Central television broadcast July 11, 2011), available at http://www.colbertnation.com/the-colbert-report-videos/391552/july-112011/anti-frack-attack.

4. See, e.g., David Greene, Daniel Yergin Examines America's 'Quest' for Energy, NPR (Sept. 20, 2011), http://www.npr.org/2011/09/20/140606249/daniel-yergin-examines-americas-quest-forenergy.

5. U.S. Envtl. Prot. Agency, Draft Plan to Study the Potential Impacts of Hydraulic Fracturing on Drinking WATER Resources 6 (2011) [hereinafter Potential IMPACTS OF FRACTURING], available at http://o.aolcdn.com/os/industry/energy/photos/EPAHydraulic-Fracturing-Draft-Plan.pdf.

6. See U.S. DeP'T OF ENERgy, Modern Shale Gas DeVelopment in the United States: A PRIMER 8-9 (2009), available at http://www.netl.doe.gov/technologies/oil-gas/publications/ EPreports/Shale_Gas_Primer_2009.pdf (explaining that unconventional sources of natural gas, such as shale gas, are likely to contribute significantly to the United States’ domestic energy needs). 
Fracking is the pressurized injection of water, sand, chemicals, and organic molecules into oil and gas formations. ${ }^{7}$ The pressure creates fractures in the formations, which act as conduits for oil and gas to flow into the well. ${ }^{8}$ For over half a century, well operators have used fracking as "a very common" method of increasing the rate and lifetime of wells' production. ${ }^{9}$ Recently, fracking's safety has been called into question. Skeptics urge that fracking causes underground gases and fracking chemicals to contaminate underground sources of drinking water (USDW). ${ }^{10}$ These concerns are most prevalent in states like New York, Pennsylvania, Ohio, Tennessee, and West Virginia, which hold the nation's most potentially productive gas shale reserves. ${ }^{11}$

The question of fracking's environmental safety has percolated to the courts. Plaintiffs in fracking cases have alleged that fracking has contaminated their domestic water sources with natural gases or fracking chemicals. ${ }^{12}$ Because environmental contamination statutes typically do

7. Norman J. Hyne, Nontechnical Guide to Petroleum Geology, Exploration, DRILLING, AND PRODUCTION 423-24 (2d ed. 2001).

8. Id. at $422-23$.

9. See id. at 425 (noting that at least half of all gas wells and nearly one-third of all oil wells drilled in the United States are fracked).

10. Sarah Hoye, 'Fracking' Protestors Say Drilling Jobs Not Worth Environmental Risks, CNN (Sept. 20, 2011, 8:58 AM), http://www.cnn.com/2011/US/09/20/philadelphia.fracking.protests/. Experts in Ohio also worry that the underground disposal of fracking fluids caused a recent 4.0 magnitude earthquake. Kim Palmer, Ohio Earthquake Was Not a Natural Event, Expert Says, REUTERS, (Jan. 3 2012, 7:40 PM), http://www.reuters.com/article/2012/01/04/us-earthquake-ohioidUSTRE80302220120104.

11. Hoye, supra note 10. Fracking is increasingly prevalent in states like Kansas, as well, where new horizontal fracking techniques can revitalize older fields. Roxana Hegeman, New Technologies Put Kansas on Cusp of Oil Boom, KAN. CiTY STAR, Apr. 8, 2012, http://www.kansascity.com/2012/04/08/3542980/new-technologies-put-kansas-on.html. In Kansas, the relatively robust state regulatory agency cannot keep up with a $300 \%$ increase in permits for horizontal fracking. Christina Marie, Kansas Seeks to Beef Up Budget to Deal With Fracking, KAN. PUB. RADIO (Jan. 29, 2012), http://kansaspublicradio.org/news/1769-kansas-seeks-to-beef-upbudget-to-deal-with-fracking. One could predict that an increase in complaints of groundwater contamination will accompany the rise in fracking.

12. See, e.g., Berish v. Sw. Energy Prod. Co., 763 F. Supp. 2d 702, 704 (M.D. Pa. 2011) (noting that plaintiffs alleged "pollutants and other industrial waste, including the fracking fluid and other hazardous chemicals such as barium and strontium, were discharged into the ground and contaminated the water supply used by the Plaintiffs"); Fiorentino v. Cabot Oil \& Gas Corp., 750 F. Supp. 2d 506, 509 (M.D. Pa. 2010) ("Plaintiffs allege that Defendants improperly conducted hydrofracturing and other natural gas production activities that allowed the release of methane, natural gas, and other toxins onto Plaintiffs' land and into their groundwater.” (footnote omitted)). For more cases in which plaintiffs allege groundwater contamination or personal injury from fracking activities, see Bombardiere v. Schlumberger Tech. Corp., No. 1:11-CV-50, 2011 WL 2443691, *1 (N.D. W. Va. June 14, 2011); Plaintiff's Original Petition at 1, Parr v. Aruba Petroleum, Inc., No. 11-02650-E (Dallas Cnty. Ct. March 8, 2011); Plaintiff's Original Complaint at 3-4, Mitchell v. Encana Oil \& Gas (USA), Inc., No. 3:10-CV-02555-L (N.D. Tex. Dec. 15, 2010); 
not apply to petroleum pollution, and provide for only remediation costs when they do, these plaintiffs assert common law tort claims. ${ }^{13}$ Specifically, plaintiffs in fracking cases tend to claim common law trespass, nuisance, and strict liability for abnormally dangerous activities. ${ }^{14}$ This Comment examines plaintiffs' strict liability claims for injuries arising as a result of fracking. Trespass, unlike strict liability, has received ample treatment from the academy ${ }^{15}$ and, recently, the courts. $^{16}$ The law, though not settled, is at least thoroughly analyzed. Nuisance and strict liability claims are not. The laws of nuisance and strict liability intersect and overlap so as to lead many courts to analyze them together. ${ }^{17}$ Therefore, much of this Comment's analysis is germane to both claims.

Whether fracking is an abnormally dangerous activity for purposes of strict liability appears to be an issue of first impression. That larger issue primarily turns on a smaller one: whether fracking accidents-or "fraccidents" - are avoidable or unavoidable. To that end, this Comment argues that when practiced with reasonable care and in the vicinity of

Plaintiff's Original Complaint at 2-3, Harris v. Devon Energy Prod. Co., No. 4:10-CV-00708-MHSALM (E.D. Tex. Dec. 15, 2010).

To date, no plaintiff has claimed damages from a fracking-induced earthquake. Because only the disposal of fluids from fracking - not fracking itself-has been linked to earthquakes, this Comment does not attempt to analyze liability for such earthquakes. Rather, the issue of liability for fluid injection and waste disposal is separate from strict liability for fracking, which is presented here. For a study of liability for earthquakes induced by fluid injection, waste disposal, and secondary oil and gas recovery, see Darlene A. Cypser \& Scott D. Davis, Liability For Induced Earthquakes, 9 J. ENVTL. L. \& LiTIG. 551 (1994).

13. See Alexandra B. Klass, From Reservoirs to Remediation: The Impact of CERCLA on Common Law Strict Liability Environmental Claims, 39 WAKE FOREST L. REV. 903, 904-05, 92526 (2004) (identifying the limitations of federal environmental statutes, including their inapplicability to petroleum and limited damage rewards). For a detailed discussion of common law actions against polluters, including oil and gas polluters, see Robert L. Glicksman, A Guide to Kansas Common Law Actions Against Industrial Pollution Sources, 33 U. KAN. L. REV. 621 (1985).

14. See, e.g., Berish, 763 F. Supp. 2d at 704 (noting the various claims that plaintiffs alleged); Fiorentino, 750 F. Supp. 2d at 508 (same).

15. See, e.g., Owen L. Anderson, Subsurface “Trespass”: A Man's Subsurface Is Not His Castle, 49 WASHBURN L.J. 247, 250 (2010) (arguing that "[a] land or mineral owner should not be permitted to recover money damages for mere loss of speculative value resulting from a subsurface trespass").

16. See, e.g., Coastal Oil \& Gas Corp. v. Garza Energy Trust, 268 S.W.3d 1, 17 (Tex. 2008) (holding that the rule of capture precludes trespass claims for damages for drainage by fracking).

17. E.g., Mowrer v. Ashland Oil \& Ref. Co., 518 F.2d 659, 662 (7th Cir. 1975) (recognizing that strict liability for abnormally dangerous activities and private nuisance are conceptually similar - maybe even identical_enough to be "amalgamated”); see also RESTATEMENT (SECOND) OF TORTS § $520 \mathrm{cmt}$. c (1977) (noting the conceptual similarities between nuisance and strict liability for abnormally dangerous activities). 
other petroleum production, fraccidents are avoidable, and thus, fracking is not abnormally dangerous. Instead of strict liability, courts should combine a negligence standard with res ipsa loquitur to determine liability of fracking companies that contaminate water sources.

Part II.A of this Comment will present background on the process and known environmental impact of fracking. Part II.B will survey the development and current laws of strict liability for abnormally dangerous activities, negligence, and res ipsa loquitur. Part III will then apply the Second Restatement of Torts' factors of strict liability to fracking. Part IV will conclude with recommendations for courts to apply res ipsa loquitur in fracking cases.

\section{BACKGROUND}

\section{A. Hydraulic Fracturing: Description, History, and Environmental Impact}

An analysis of whether fracking qualifies as an abnormally dangerous activity should start with a background survey both of fracking and strict liability jurisprudence. Therefore, this section will discuss both subjects separately, beginning with fracking. Fracking is a highly technical process of oil- and gas-well stimulation. ${ }^{18}$ The engineering theories and formulae that underlie fracking are beyond the scope of this discussion. ${ }^{19}$ A mere survey of the history, basic methods, and environmental impacts of fracking suffices as background for an analysis of whether the activity is abnormally dangerous as a matter of law.

\section{Description and History of Fracking}

Fracking is a standard method for stimulating greater production of oil and gas from wells. ${ }^{20}$ The process, often called a "frac job," ${ }^{21}$ creates and preserves cracks or fractures in underground rock formations that hold oil and gas reserves. ${ }^{22}$ The otherwise trapped oil and gas in these

18. See generally HYNE, supra note 7, at 423-26.

19. For a detailed discussion of the theoretical and technical foundations of fracking, see 2 G.C. HOWARD \& C.R. FAST, HYDRAULIC FRACTURING (Henry L. Doherty ed., 1970).

20. Id. § 2.1.

21. HYNE, supra note 7, at 424.

22. HOWARD \& FAST, supra note 19, § 2.1. 
formations drains through the fractures into the well bore, allowing the well operators to pump it to the surface. ${ }^{23}$ In essence, fracking opens up space in petroleum-producing formations. ${ }^{24}$ That space allows oil and gas to pass into the well at a greater rate and in greater quantities. ${ }^{25}$

Gas production companies developed fracking in the Hugoton field of western Kansas in $1947^{26}$ as a safer and more effective method to stimulate natural gas wells. ${ }^{27}$ The process has since matured into an industry standard and has proliferated across the United States. ${ }^{28}$ The National Petroleum Council has estimated that natural gas producers will frac eight out of ten natural gas wells they drill in the coming five years. $^{29}$

\section{The Fracking Process}

Fracking's primary application is to increase well productivity, though other applications exist. ${ }^{30}$ Regardless of its specific purpose, fracking proceeds in three basic steps. ${ }^{31}$ First, several large pump trucks inject a pad of "frac fluid" into the subject well. ${ }^{32}$ Frac fluid is a viscous gel made up of over $90 \%$ water mixed with chemical polymers. ${ }^{33}$ The pad is injected at a higher rate than the rock formation can accept,

23. Id. § 1.6.

24. U.S. DeP'T of Energy, Hydraulic Fracturing White Paper A-1 (2004) [hereinafter DOE WHITE PAPER 2004], available at http://www.epa.gov/ogwdw/uic/pdfs/cbmstudy_attach_uic_ append_a_doe_whitepaper.pdf.

25. Id.

26. Id.; HOWARD \& FAST, supra note 19, § 1.5 .

27. See HOWARD \& FAST, supra note 19, § 1.3 (noting that other methods were more dangerous).

28. HYNE, supra note 7, at 425.

29. James M. Inhofe \& Frank Fannon, Energy and the Environment: The Future of Natural Gas in America, 26 ENERGY L.J. 349, 370 (2005).

30. DOE White PAPER 2004, supra note 24, at A-1 to A-2. Fracking also may (1) "[i]ncrease the flow rate of oil and/or gas from low permeability reservoirs," (2) "[i]ncrease the flow rate of oil and/or gas from wells that have been damaged," (3) "[c]onnect the natural fractures and/or cleats in a formation to the wellbore," (4) "[d]ecrease the pressure drop around the well to minimize problems with asphaltine and/or paraffin deposition," (5) "[i]ncrease the area of drainage or the amount of formation in contact with the wellbore," and (6) "[c]onnect the full vertical extent of a reservoir to a slanted or horizontal well.” Id. at A-2.

31. HYNE, supra note 7, at 424.

32. Id.

33. Id. at 423; U.S. EnVtl. Prot. Agency, EVAluation of Impacts to Underground SOURCES OF DRINKING WATER BY HYDRAULIC FRACTURING OF COALBED METHANE RESERVOIRS 4-2 (2004) [hereinafter EPA USDW EVALUATION 2004]. 
causing the formation to crack. ${ }^{34}$ The specific chemicals used in frac fluid vary from job to job. ${ }^{35}$ Some of these fluids may cause negative human health effects in their pure form. ${ }^{36}$ The same chemicals in frac fluids, however, are significantly diluted by water ${ }^{37}$ and are toxic only through direct inhalation, ingestion, or skin contact. ${ }^{38}$

As the initial fractures widen, treatment proceeds to the second step: injecting propping agents, or proppants, into the well with the frac fluid. ${ }^{39}$ Proppants are tiny spheres intended to hold open the fractures permanently. ${ }^{40}$ Sand is the most common proppant; ceramic beads sometimes hold open deeper formations. ${ }^{41}$

The third and final stage of fracking is known as back flush or flow back. $^{42}$ In this stage, pumps bring the frac fluid back to surface, leaving the proppants behind. ${ }^{43}$ Back flush typically retrieves up to $80 \%$ of frac fluids from underground. ${ }^{44}$ Wells may undergo fracking multiple times, using differing types and amounts of frac fluids and proppants. ${ }^{45}$

\section{Environmental Impact of Fracking}

Recent concerns over the environmental impact of fracking are not novel. Generally, plaintiffs in fracking litigation allege that frac fluids and formation gases have contaminated their USDW. ${ }^{46}$ In 2004, a series of similar allegations led the Environmental Protection Agency (EPA) to study the potential for frac fluids from the fracking of coalbed methane wells to contaminate USDW. ${ }^{47}$ The EPA "concluded that the injection of

\footnotetext{
34. DOE WHITE PAPER 2004, supra note 24, at A-1.

35. See EPA USDW EVALUATION 2004, supra note 33, at 3-5 (discussing a variety of chemicals comprising hydraulic fracturing fluids).

36. Id. at 4-3, 4-10 tbl. 4-1. When present in harmful concentrations, these chemicals can cause a range of health effects in humans, including mild skin and eye irritation, nausea, diarrhea and abdominal pain, severe burns and tissue damage, "heritable genetic damage," internal organ damage, and cancer. Id. at 4-10 tbl. 4-1.

37. Id. at 4-3.

38. Id. at 4-17, 4-10 tbl. 4-1.

39. HYNE, supra note 7, at 424.

40. Id.

41. DOE WhITE PAPER 2004, supra note 24, at A-1.

42. HYNE, supra note 7, at 424.

43. Id.

44. EPA USDW EVALUATION 2004, supra note 33, at 4-15.

45. HYNE, supra note 7, at 426.

46. See, e.g., cases and sources cited supra note 12 .

47. EPA USDW EVALUATION 2004, supra note 33, at 1-2.
} 
hydraulic fracturing fluids into coalbed methane wells poses little or no threat to USDW." ${ }^{48}$ Importantly, though, shale and other natural gas formations sit much deeper underground than coalbed methane formations and are geologically separated from drinking water sources by thousands of feet of rock. ${ }^{49}$

Concerns over drinking water contamination rest on the potential for frac fluids or formation gases to communicate with an underground water supply through fractures created by fracking. ${ }^{50}$ Indeed, most formations fracture vertically, ${ }^{51}$ making communication between a shallow aquifer and a much deeper petroleum formation hypothetically possible. $^{52}$ The EPA planned a multi-phase study to investigate this possibility. ${ }^{53}$ In Phase I, the EPA conducted a literature review of existing fracking science and coal basin geology, requested information from state regulatory agencies and the public about groundwater contamination believed to be from fracking, reviewed reports of contamination, and "[c]onducted field visits" of coalbed methane fields. ${ }^{54}$ Phase II would have included a site-specific, detailed study of contamination complaints, ${ }^{55}$ but because Phase I concluded that no evidence existed directly linking fracking to water quality degradation, Phase II never occurred. ${ }^{56}$

The EPA found that the risk of frac fluid migration into underground water supplies is significantly reduced by three factors: (1) the concentration and flow back of fluids; (2) underground mitigating effects; and (3) dense geological barriers. ${ }^{57}$ The EPA concluded that the low concentration of potentially toxic chemicals in frac fluids, ${ }^{58}$ coupled

48. See id. at 7-5.

49. J. DANIEL ARTHUR, BRIAN BOHM \& MARK LAYNE, HYDRAULIC FraCturing CONSIDERATions for Natural Gas Wells of the MARCEllus Shale 4 (2008), available at www.dec.ny.gov/docs/materials_minerals_pdf/GWPCMarcellus.pdf.

50. EPA USDW EVALUATION 2004, supra note 33, at 1-6.

51. DOE WHITE PAPER 2004, supra note 24, at A-1.

52. EPA USDW EVALUATION 2004, supra note 33, at 7-4 (acknowledging that "[d]eep vertical fractures can propagate vertically to shallower depths and develop a horizontal component" and noting that deeper reservoirs tend to fracture vertically).

53. See id. at 1-7.

54. Id.

55. Id.

56. Id. at 7-5.

57. Id.

58. See id. at 4-3 (acknowledging that "fluid and fluid additives may contain constituents of potential concern," but also noting that the constituents are "significantly diluted”). 
with effective fluid recovery practices, ${ }^{59}$ significantly reduced any risk to water supplies. Dilution, dispersion, and diffusion by groundwater, adsorption by the formation rock, and even biodegradation mitigate the risks posed by frac fluids that flow back does not recover. ${ }^{60}$

The EPA further concluded that a thick shale formation would act as a barrier to confine the growth of fractures, thereby protecting water supplies from fracking. ${ }^{61}$ Shale has low permeability and is a solid-not porous or fractured-rock formation. ${ }^{62}$ These properties make shale an effective barrier to fracture growth and frac fluid migration. ${ }^{63}$ Thousands of feet - typically a mile or more-of shale and other formation rocks isolate fracked formations from shallower fresh water aquifers. ${ }^{64}$ Put simply, shale formations shield underground water supplies from the effects of fracking. Shale provides another method of defense against frac fluid migration because it is "usually [chemically] reactive with water-based fluids." "65 Water reacts with shale to "form an increasingly viscous, dehydrated slurry within the fracture, which will eventually seal the fracture over a long time period." ${ }^{66}$ As a result, water-based fluidslike frac fluids-cannot migrate through shale. ${ }^{67}$

The EPA also determined that sources other than fracking caused reports of methane and hydrogen sulfide gases in water supplies. ${ }^{68}$ Evidence showed that these gases entered drinking water sources through naturally occurring fractures, ${ }^{69}$ improperly sealed natural gas wells, and negligently abandoned gas wells. ${ }^{70}$ Plugging and sealing old gas wells has apparently mitigated the problem in New Mexico, suggesting that existing gas production, gas drilling, and natural fractures cause

\footnotetext{
59. See id. at 4-15 (noting a $61 \%$ recovery in one study).

60. Id. at 4-16 to $4-17$.

61. Id. at 7-4.

62. Id.

63. Id.

64. ARTHUR, BoHm \& LAYNE, supra note 49, at 2 tbl. 1.

65. A.K. Wojtanowicz, Environmental Control Technology in Petroleum Drilling and Production, in ENVIRONMENTAL TECHNOLOGY IN THE OIL INDUSTRY 73, 140 (S.T. Orszulik ed., 1997).

66. Id. (describing shale's reactivity with water-based fluids in the context of injected oilfield waste slurries, which are analogous to frac fluids).

67. Id.

68. See EPA USDW Evaluation 2004, supra note 33, at 6-2 to 6-3, 6-8 (describing complaints concerning alleged methane and hydrogen sulfide in water wells and concluding that "[n]o reports provide direct information regarding hydraulic fracturing").

69. Id. 6-8.

70. Id. at 6-1 to 6-2.
} 
groundwater pollution-not fracking. ${ }^{71}$

The EPA has initiated a second investigation of fracking to uncover any potential impacts of hydraulic fracturing on drinking water and groundwater. $^{72}$ According to the EPA, the recent expansion and forecasted growth of natural gas exploration in "hard-to-extract sources" warrants further study of fracking. ${ }^{73}$ Though the EPA will not publish a full report until late in 2012, and the final report not until $2014,{ }^{74}$ the agency in late 2011 released a draft report of its findings from an investigation of groundwater contamination in the Pavillion Gas Field of Wyoming. ${ }^{75}$ The draft report theorized a link between fracking and groundwater contamination. ${ }^{76}$ The EPA conducted the study by collecting groundwater samples and drilling two monitoring wells. ${ }^{77}$ The resulting data indicated the presence of contamination from shallow surface sources, such as oil field pits and "deep sources of contamination," 78 but urged further investigation to determine whether organic contaminants associated with fracking have contaminated domestic water wells. ${ }^{79}$ Among the EPA's reasons for linking fracking with the contamination was that fracking in Pavillion happened in "thin discontinuous sandstone” formations, which failed to effectively shield water sources. $^{80}$ The EPA further found that many wells lacked adequate cement casing to protect the well from surrounding water sources. ${ }^{81}$ Ultimately, the EPA recommended more data collection and greater emphasis on well construction and integrity. ${ }^{82}$ Implementing these recommendations, the EPA stated, "would decrease the likelihood of

71. See id. at 7-2 (discussing New Mexico's "plugging and abandonment program”); see also Soraghan, supra note 1 (noting recent controversy over and media coverage of hydraulic fracturing).

72. POTENTIAL IMPACTS OF FRACTURING, supra note 5, at 1.

73. Questions and Answers About EPA's Hydraulic Fracturing Study?, U.S. ENVTL. PROT. AGENCY, http://www.epa.gov/hfstudy/questions.html (last updated Mar. 16, 2012).

74. EPA's Study of Hydraulic Fracturing and Its Potential Impact on Drinking Water Resources, U.S. ENVTL. PROT. AGENCY, http://www.epa.gov/hfstudy/ (last updated Mar. 19, 2012).

75. See generally U.S. EnVtl. Prot. Agency, Draft, InVestigation of Ground Water CONTAMINATION NEAR PAVILLION, WYOMING (2011) available at http://www.epa.gov/region8/ superfund/wy/pavillion/EPA_ReportOnPavillion_Dec-8-2011.pdf [hereinafter EPA USDW EVALUATION DRAFT 2011].

76. Id. at 33, 39.

77. Id. at 5 .

78. Id. at 33 .

79. Id. at 39 .

80. See id. at 37.

81. Id. at 38.

82. Id. at 39 . 
impact to ground water” from fracking. ${ }^{83}$

83. Id. 
The Governor of Wyoming and the natural gas industry have criticized the validity of the EPA's draft report. ${ }^{84}$ In particular, critics fear that the EPA will not " give deference to the unique geology and hydrology' in the Pavillion [field]." "85 The Pavillion field is a relatively shallow coalbed methane field. ${ }^{86}$ Coalbed methane fields are unique because their shallow geology requires fracking directly into USDWs. ${ }^{87}$ In contrast, typical natural gas recovery through fracking occurs at much greater depths relative to USDW. ${ }^{88}$ The EPA's theory in the draft report is, arguably, inapplicable outside of coalbed methane fields because unconventional shale plays in Pennsylvania, New York, and Tennessee, ${ }^{89}$ for example, have significantly different geology than the coalbed field in the Pavillion study. ${ }^{90}$

\section{B. The Development of Strict Liability for Abnormally Dangerous Activities}

This section surveys the development of the doctrine of strict liability for abnormally dangerous activities. It will briefly trace the doctrine's evolution into its modern form, established in Rylands $v$. Fletcher, ${ }^{91}$ to its treatment in the First and Second Restatements of Torts. Lastly, this section will discuss negligence and res ipsa loquitur as alternatives to strict liability.

84. Group: Wyo. Siding With Industry on Fracking Issue, CBSNEWs (Jan. 28, 2012, 11:10 AM), http://www.cbsnews.com/8301-505245_162-57361077/group-wyo-siding-with-industry-onfracking-issue/.

85. Id.

86. See EPA USDW EVALUATION DRAFT 2011, supra note 75, at 1-2 (explaining that fracking in the field occurred at depths "as shallow as $372 \mathrm{~m}$ (1220 ft.)").

87. Id. at 39 (citing EPA USDW EVALUATION 2004, supra note 33).

88. ARTHUR, BOHM \& LAYNE, supra note 49, at 3 (noting that gas bearing shale can sit below 12,000 feet).

89. See Hoye, supra note 10 (discussing the location of unconventional shale plays, which are not coalbed methane producers).

90. See EPA USDW Evaluation 2004, supra note 33, at 7-4 ("Most coal seams currently used for methane production are relatively shallow compared to [other] conventional ... production wells ....").

91. (1866) 1 L.R. Ex. 265, aff'd by, (1868) L.R. 3 H.L. 330. 


\section{The Origins of Strict Liability}

Modern negligence and strict liability emerged in the Industrial Revolution. $^{92}$ Strict liability means liability despite intent or negligence. ${ }^{93}$ In 1850, just one year before Brown v. Kendall announced the modern concept of negligence, ${ }^{94}$ New York's highest court laid down the rule of strict liability for blasting in Hay v. Cohoes Co. ${ }^{95}$ The rule allowed plaintiffs to recover damages caused by a defendant's blasting operations without proving negligence. ${ }^{96}$ The Hay rule was influential but limited to the use of explosives. ${ }^{97}$ Today's concept of strict liability for abnormally dangerous activities cuts a wider swath.

Today's strict liability rule originated in the famous 1868 English case of Rylands v. Fletcher. ${ }^{98}$ In Rylands, the defendant had built and maintained on his land a fresh water reservoir. ${ }^{99}$ The reservoir filled and burst, sending massive amounts of water through ancient underground coal shafts and into the plaintiff's neighboring coalmine. ${ }^{100}$ The Exchequer Chamber held the defendant liable even though he was unaware of the ancient mineshafts beneath his reservoir and was otherwise not negligent. ${ }^{101}$ Justice Blackburn explained the rule:

We think that the true rule of law is, that the person who for his own purposes brings on his lands and collects and keeps there anything likely to do mischief if it escapes, must keep it in at his peril, and, if he does not do so, is prima facie answerable for all the damage which is the natural consequence of its escape $\ldots{ }^{102}$

Lord Cairns affirmed the Exchequer's decision and ratified Justice Blackburn's principle, but he included an important limitation: that an activity must also constitute a "non-natural use" of the land. ${ }^{103}$

92. Frank J. VANDALL, StRict Liability: LEgAL AND ECONOMiC ANALYSIS 4 (1989).

93. W. Page Keeton et Al., Prosser And KeEton on Torts $§ 75$, at 534 (5th ed. 1984).

94. 60 Mass. (6 Cush.) 292, 297-98 (1850).

95. 2 N.Y. 159, 161-67 (1849).

96. Id. at 163.

97. VANDALL, supra note 92, at 5-6.

98. (1866) 1 L.R. Ex. 265, aff'd by, (1868) L.R. 3 H.L. 330.

99. Id. at 278.

100. Id. at 278-79.

101. Id. at 279-80.

102. Id. at 279 .

103. Gerald W. Boston, Strict Liability for Abnormally Dangerous Activity: The Negligence Barrier, 36 SAN DIEGO L. REV. 597, 603-05 (1999) (internal quotation marks omitted). 
Therefore, the Rylands rule imposes liability on a defendant who damages his neighbor "by a thing or activity unduly dangerous and inappropriate to the place where it is maintained, in the light of the character of that place and its surroundings," even if the defendant was not negligent. ${ }^{104}$

Courts in the United States initially gave a mixed interpretation to the Rylands principle. ${ }^{105}$ Courts that rejected the rule reasoned that it "place[d] too heavy a burden on [the country's] industrial development."106 In 1873, New York’s high court in Losee v. Buchanan articulated this notion with particular clarity:

We must have factories, machinery, dams, canals[,] and railroads. They are demanded by the manifold wants of mankind, and lay at the basis of all our civilization. If I have any of these upon my lands, and they are not a nuisance and are not so managed as to become such, I am not responsible for any damage they accidentally and unavoidably do my neighbor. He receives his compensation for such damage by the general good, in which he shares, and the right which he has to place the same things upon his lands. ${ }^{107}$

Decisions like this hewed closely to the "subsidy theory," which argues that negligence subsidizes industry by immunizing it from liability for accidental harm to others. ${ }^{108}$

The U.S. courts that adopted the Rylands rule did so largely under the theory of "enterprise liability." 109 Under this theory, business enterprises are made to insure others from any injury or harm resulting from the enterprises' activities. ${ }^{110}$ Minnesota led the charge for enterprise liability in the 1924 case of Bridgeman-Russell Co. v. City of Duluth. $^{111}$ The Minnesota Supreme Court stated the definition of enterprise liability: "In such a case, even though negligence be absent, natural justice would seem to demand that the enterprise ... should stand

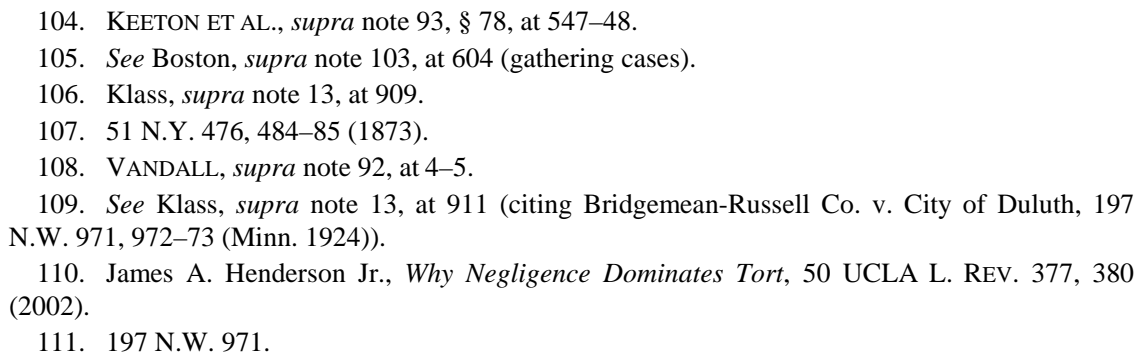


the loss rather than the individual. It is too heavy a burden upon one.”112 The Losee and Bridgeman-Russell cases illustrate the clash between enterprise subsidy and enterprise liability. ${ }^{113}$ "[T]he debate over the "benefits and burdens of 'enterprise' liability for hazardous activities ... continues today."114

\section{Strict Liability in the Restatements of Torts}

a. The First Restatement

Today, most courts follow the doctrine of strict liability for abnormally dangerous activities articulated in the Restatement of Torts. ${ }^{115}$ Professor Francis Bohlen reported the Restatement of Torts in $1938,{ }^{116}$ when the doctrine of strict liability for abnormally dangerous activities was still limited to the Rylands rule. ${ }^{117}$ Despite this factperhaps, in spite of it-Professor Bohlen proposed a comparatively broad rule of strict liability in the Restatement. ${ }^{118}$ The rule called for strict liability for "ultrahazardous activities."119 Ultrahazardous activities have two necessary elements. ${ }^{120}$ First, such an activity must "necessarily involve[] a risk of serious harm to the person, land[,] or chattels of others [that] cannot be eliminated by the exercise of the utmost care."121 Second, such an activity must "not [be] a matter of common usage."122 Essentially, an activity qualifies as ultrahazardous if its utility "does not justify the risk inseparable from it.”"123

Professor Bohlen's ultrahazardous standard was broader than the Rylands rule in two primary ways. ${ }^{124}$ First, the "non-natural us[e]" element of the Rylands test gave way for the "matter of common usage"

\footnotetext{
112. Id. at 972 .

113. See text accompanying notes $106-07$ and $110-11$.

114. Klass, supra note 13, at 911.

115. Id. at 912 .

116. Boston, supra note 103, at 604-05.

117. Id.

118. See id.

119. Id.; see also RESTATEMENT OF TORTS § 519 (1938).

120. See RESTATEMENT OF TORTS $§ 520$.

121. Id. § 520(a).

122. Id. § 520(b).

123. Id. § $520 \mathrm{cmt}$. a.

124. See Boston, supra note 103, at 605-06.
} 
element of ultrahazardous activities. ${ }^{125}$ The common usage provision apparently extended strict liability to activities that are not "customarily carried on by the great mass of mankind."126 Second, the ultrahazardous principle expanded the definition of "land." ${ }^{\text {227 }}$ The facts of Rylands limited defendant's liability to adjacent landowners. ${ }^{128}$ The ultrahazardous principle extends a defendant's liability to any person harmed by his use of dangerous instrumentalities or operations. ${ }^{129}$ The Restatement further departed from Rylands by requiring an activity to be "unavoidably" dangerous, ${ }^{130}$ such that it involves a risk that "cannot be eliminated by the exercise of the utmost care." 131

\section{b. The Second Restatement}

One of the ultrahazardous rule's harshest critics, Dean William Prosser, was the Reporter for the Restatement (Second) of Torts. ${ }^{132}$ The law of strict liability underwent another sea of change when American Law Institute published the Second Restatement in 1977. ${ }^{133}$ The Second Restatement replaced "ultrahazardous" with "abnormally dangerous."134 The new name accompanied a new set of criteria to identify those activities that qualify for strict liability-the six-factor test in section $520:^{135}$

(a) existence of a high degree of risk of some harm to the person, land or chattels of others;

(b) likelihood that the harm that results from it will be great;

(c) inability to eliminate the risk by the exercise of reasonable care;

(d) extent to which the activity is not a matter of common usage;

(e) inappropriateness of the activity to the place where it is carried on; and

\footnotetext{
125. Id. at 605 .

126. RESTATEMENT OF TORTS $\S 520 \mathrm{cmt}$. e.

127. See Boston, supra note 103, at 605-06.

128. Id. at 605 .

129. RESTATEMENT OF TORTS $\S 520 \mathrm{cmts}$. b-d. requirement).

131. RESTATEMENT OF TORTS § 520(b).

132. Boston, supra note 103, at 616 .

133. Klass, supra note 13, at 916.

134. RESTATEMENT (SECOND) OF TORTS § 519 (1977)

135. Klass, supra note 13, at 914.
}

130. Id. $\S 520 \mathrm{cmt}$. a; see also Boston, supra note 103, at 612 (noting that Bohlen’s comment that the inherent dangers of air travel made it dangerous corroborates the existence of this new 
(f) extent to which its value to the community is outweighed by its dangerous attributes. ${ }^{136}$

Dean Prosser explained that shifting to a factors test was necessary because defining "abnormally dangerous" to "cover the myriad kind of cases potentially involved", would be impossible. ${ }^{137}$

The Second Restatement's test has faced serious scrutiny from academics, in particular, Professor Gerald Boston. Professor Boston asserts that the negligence system has obviated the doctrine of strict liability as it has been interpreted. ${ }^{138}$ Professor Boston further argues that the factors in section 520 create inconsistent results, which promote litigation. $^{139}$

In his analysis, Professor Boston identifies a number of signature characteristics of the factors in section 520. First, factor (e) seems to reincorporate the "appropriateness of the activity to its surroundings"essentially, Lord Cairns' "non-natural" rule-into the analysis. ${ }^{140}$ Factor (d) also reincorporates the "common usage" requirement from the First Restatement. ${ }^{141}$ The Second Restatement's comments explain how these factors interact using the example of oil wells, noting that "[t]he dangers incident to the operation [of oil wells] are characteristic of oil lands and not of lands in general." "142 As comment $\mathrm{j}$ states, however, oil wells are appropriate when located "where there is oil."143 The comments resolve this tension using factor (f), which states that "a properly conducted oil or gas well, at least in a rural area, is not regarded as abnormally dangerous" because of its value to the community. ${ }^{144}$ Apparently, Dean Prosser intended section 520 to accomplish this sort of balancing of countervailing factors.

Another notable quality of section 520 is that no factor is supposed

136. RESTATEMENT (SECOND) OF TORTS § 520.

137. Boston, supra note 103, at 620 (citing Restatement (SECOND) OF TORTS, ch. 21, at 72 (Council Draft No. 15, 1963)).

138. Boston, supra note 103, at 598.

139. Id. at 627 (examining Page Keeton's criticism of Prosser's factors test, including that the test promotes litigation by creating inconsistent results).

140. See id. at 624; see also KeETON ET AL., supra note 93, § 78, at 547-48 (stating Lord Cairns' rule that strict liability applies when an activity occurs in an area to which it is not naturally suited).

141. See Boston, supra note 103, at 659-61 (discussing interpretations of factor (d) that include the "common usage" requirement); see also RESTATEMENT OF TORTS § 520 (1938).

142. RESTATEMENT (SECOND) OF TORTS $§ 520 \mathrm{cmt}$. i.

143. Id. § $520 \mathrm{cmt}$. j.

144. Id. $\S 520 \mathrm{cmt} . \mathrm{k}$. 
to be determinative. ${ }^{145}$ That rule has not been borne out by the case law. ${ }^{146}$ Instead, Professor Boston claims that courts tend to avoid the mire of balancing factors (d), (e), and (f) by deciding cases based on (a) and (b), or, more often, (c) ${ }^{147}$ As a practical matter, courts tend to apply strict liability when these factors-in particular, factor (c)-weigh in favor of such application. ${ }^{148}$

Factor (c) retains the spirit of the requirement that the "risk... cannot be eliminated by the exercise of the utmost care"149 by requiring that the risk cannot be eliminated by the exercise of "reasonable care.", Courts have interpreted this factor to require only that due care eliminate the great risk of harm; the activity need not be made completely harmless. ${ }^{151}$ Consequently, plaintiffs often prove negligence in the alternative because, more often than not, some amount of care by the defendant would have prevented the injury. ${ }^{152}$ In other words, most accidents are avoidable. Many courts, therefore, treat factor (c) more as an element than a factor because, in its absence, a plaintiff's claim becomes tantamount to negligence. ${ }^{153}$

Finally, section 520 is notable for its retreat from enterprise liability. As comment $\mathrm{j}$ of the Second Restatement explains, "[i]f these activities are of sufficient value to the community ... they may not be regarded as abnormally dangerous." ${ }^{254}$ Comment $\mathrm{j}$ echoes the holding in Losee that the benefits of the enterprise compensate accident victims for their

145. See id. $\S 520 \mathrm{cmt}$. $\mathrm{f}$ ("In determining whether the danger is abnormal, the factors listed in [subsections] (a) to (f) ... are all to be considered, and are all of importance. Any one of them is not necessarily sufficient of itself in a particular case, and ordinarily several of them will be required for strict liability.”).

146. See Boston, supra note 103, at 629 ("[F]actor (f) ... finds little historical basis and even less doctrinal justification.”).

147. Id. at 622,629 .

148. Id.

149. See RESTATEMENT OF TORTS §520(c) (1938) (requiring as an element of ultrahazardous activity the inability to eliminate the risk of serious harm with use of utmost care).

150. RESTATEMENT (SECOND) OF TORTS § 520(c).

151. See, e.g., New Meadows Holding Co. v. Wash. Water Power Co., 687 P.2d 212, 216 (Wash. 1984) (en banc) (holding that exercise of reasonable care eliminated the "high degree of risk" caused by gas transportation, and that it was unnecessary to eliminate all risk).

152. See Boston, supra note 103, at 629 (noting that the plaintiff must prove some likelihood of harm, and the gravity of that harm, for both negligence and strict liability).

153. See id. at 630 ("It seems pretty clear that the availability of a [strict liability for abnormally dangerous activities] cause of action will be fairly limited because, in the vast majority of situations, a plaintiff will be able to prove negligence because some amount of care exercised by the defendant would have prevented the injury.”).

154. RESTATEMENT (SECOND) OF TORTS $§ 520 \mathrm{cmt}$. j. 
accidental losses from it. ${ }^{155}$ Professor Boston argues that when courts moved away from enterprise liability, they eroded the need, and justification, for strict liability. ${ }^{156}$

\section{The Rise of Negligence as an Alternative to Strict Liability}

The third portion of this survey of strict liability law will review the laws of negligence and res ipsa loquitur. It will summarize the general thrust of strict liability criticism, namely that negligence is a better standard. Then, it will analyze the rule of res ipsa loquitur, which is sometimes considered a compromise between the two positions. ${ }^{157}$ For this Comment's sake, one should view strict liability, negligence, and res ipsa loquitur as three points along a spectrum of liability, with res ipsa loquitur in the middle of the two extremes.

\section{a. Arguments for Negligence}

Some from the bench and bar have lauded negligence as an alternative standard to strict liability. ${ }^{158}$ An essential difference between the two torts is how each assigns liability for damages caused by unavoidable accidents. ${ }^{159}$ An unavoidable accident is "an occurrence which was not intended and which, under all the circumstances, could not have been foreseen or prevented by the exercise of reasonable precautions." 160 Strict liability assigns fault for unavoidable accidents to

155. Losee v. Buchanan, 51 N.Y. 476, 484-85 (1873).

156. Boston, supra note 103, at 601.

157. See id. at 647 (noting that res ipsa loquitur obviates the need for strict liability). Contra William K. Jones, Strict Liability for Hazardous Enterprise, 92 CoLUM. L. REV. 1705, 1735-36 (1992) (arguing that res ipsa loquitur, though an alternative to strict liability, is an inadequate one).

158. See, e.g., Boston, supra note 103, at 598 (arguing that strict liability for abnormally dangerous activities is nearly extinct because courts have concluded that negligence "functions effectively to deter the serious risks posed by such activities”); Gary T. Schwartz, The Beginning and the Possible End of the Rise of Modern American Tort Law, 26 GA. L. REV. 601, 607-08 (1992); see also Ind. Harbor Belt R.R. v. Am. Cyanamid Co., 916 F.2d 1174, 1177 (7th Cir. 1990) ("The baseline common law regime of tort liability is negligence. When it is a workable regime, because the hazards of an activity can be avoided by being careful (which is to say, nonnegligent), there is no need to switch to strict liability.”).

159. See Richard A. Posner, Strict Liability: A Comment, 2 J. Legal STUD. 205, 208 (1973) ("[F]requently the cost either to injurer or to victim of taking measures to prevent an [unavoidable] accident exceeds the expected accident cost and in such a case efficiency requires that the accident be permitted to occur. Under a negligence standard, the injurer is not liable; under strict liability, he is.”).

160. KeETON ET AL., supra note 93, § 29, at 162. 
the actor, regardless of blameworthiness. ${ }^{161}$ Negligence, on the other hand, assigns no fault for unavoidable accidents because no party is morally blameworthy. ${ }^{162}$

161. Id. § 75, at 534 .

162. Id. § 29, at 162. 
Professor James Henderson summed up the vast body of strict liability criticism with four arguments that negligence is a better standard for assigning fault: (1) tradition; (2) promotion of safety; (3) distribution of loss; and, (4) adjudicability. ${ }^{163}$ Professor Henderson's first argument is that negligence carries with it a "resonance of tradition."164 The premise here is that negligence is the "baseline common law regime of tort liability" 165 in the United States, and it has been for over 150 years. ${ }^{166}$ Further, courts should apply a negligence standard whenever it is workable. ${ }^{167}$ According to Judge Richard Posner's opinion in Indiana Harbor Belt Railroad v. American Cyanamid Co., negligence is "a workable regime" when an actor can avoid an accident by exercise of due care. ${ }^{168}$

Second, Professor Henderson cites the ability of a negligence standard to promote safety. ${ }^{169}$ Strict liability's proponents contend that the doctrine induces risk-creating actors to use greater care by placing on them the full costs of accidents. ${ }^{170}$ That means that risk-creators have an incentive to take measures to prevent accidents. ${ }^{171}$ Judge Posner has proposed that negligence induces the use of greater care as efficiently in the short run by incentivizing victims to choose firms that perform safer operations. $^{172}$

Third, Professor Henderson claims negligence achieves "a substantial measure of loss distribution." ${ }^{\text {"173 }}$ Strict liability "distributes" all losses resulting from accidents to the defendant enterprise, making the enterprise tantamount to an insurer of all victims. ${ }^{174}$ That notion suffers

\footnotetext{
163. Henderson, supra note 110, at 386, 391 (citing Schwartz, supra note 158, at 607-08).

164. Id. at 386 (internal quotation marks omitted) (quoting Schwartz, supra note 158, at 607).

165. Ind. Harbor Belt R.R. v. Am. Cyanamid Co., 916 F.2d 1174, 1177 (7th Cir. 1990).

166. See Henderson, supra note 110, at 386 (citing Schwartz, supra note 158, at 607) (observing that negligence has been the primary tort regime for at least 100 years as of 1960).

167. See Ind. Harbor Belt, 916 F.2d at 1177 (discussing circumstances under which strict liability should not be applied).

168. Id. at 1177.

169. See Henderson, supra note 110, at 386 (noting that negligence can "discourage[e] improper harmful conduct").

170. Jones, supra note 157, at 1707, 1779.

171. Posner, supra note 159, at 209.

172. Id.

173. Henderson, supra note 110, at 386 (quoting Schwartz, supra note 158, at 608) (internal quotation marks omitted).

174. See id. at 380; see also Bridgeman-Russell Co. v. City of Duluth, 197 N.W. 971, 972-73 (Minn. 1924) (holding that an enterprise should insure victims from harms arising from necessary and dangerous activities).
} 
from a deep flaw in modern times, namely, that "in most cases[,] . . it is not the innocent victim who bears the loss, but rather an insurance company." "175 Modern victims may no longer need enterprises to insure them because they have purchased that service independently. ${ }^{176}$

Finally, Professor Henderson argues that negligence is a more efficient and adjudicable regime. ${ }^{177}$ The boundaries of strict liability doctrine are indefinite, which causes two problems with respect to the adjudication of claims. ${ }^{178}$ First, the law becomes inconsistent. Whether an activity is abnormally dangerous is a matter of law. ${ }^{179}$ But, these legal questions generally turn on "fact-sensitive risk-utility-calculations.", Consistent and economical dispute resolution suffers as a result. ${ }^{181}$ Second, strict liability's vagueness likely increases the cost of litigation. ${ }^{182}$ The doctrine's indistinct parameters could expand the universe of possible claims. ${ }^{183}$ The result is more trials and more expensive trials. ${ }^{184}$ On the other hand, Professor Henderson argues that negligence is not susceptible to these adjudicability problems. ${ }^{185}$ Negligence does not require courts to set boundaries with an open-ended reasonableness standard. ${ }^{186}$ Rather, the proximate-cause requirement acts as a bright-line limitation to possible negligence claims, thereby minimizing litigation. ${ }^{187}$

b. Res Ipsa Loquitur as A Strict Liability Substitute

Somewhere between negligence and strict liability lies res ipsa

175. Mahowald v. Minn. Gas Co., 344 N.W.2d 856, 862 (Minn. 1984) (en banc).

176. See Posner, supra note 159, at 210 (discussing insurance as another option for recovery from loss).

177. See Henderson, supra note 110 , at 402-03.

178. See id. at 391; Klass, supra note 13, at 916-17.

179. RESTATEMENT (SECOND) OF TORTS § $520 \mathrm{cmt}$. l (1977).

180. Henderson, supra note 110 , at 391.

181. See id. ("But even if a strict liability system avoided self-defeating reliance on notions of fault, as long as the boundary descriptions are indeterminate, the disputes they present will defy rational, consistent resolution by means of adjudication.”).

182. Posner, supra note 159, at 209.

183. Id.

184. Id.

185. See Henderson, supra note 110 , at 402-03 (stating that "[n]egligence avoids boundary problems" and is "adjudicable").

186. Id. at 391, 402-03 (arguing that strict liability's necessary risk-utility calculations defeat the doctrine's objective of reducing transaction costs).

187. See id. at 392 ("[S]ome further limitation [on strict liability claims], akin to the proximate causation limitation in fault-based liability systems, is necessary.”). 
loquitur. Res ipsa loquitur is a "transitional step" between the two standards. ${ }^{188}$ This has led some critics of strict liability to hail res ipsa loquitur as an alternative to strict liability and its supporters to condemn it as such. ${ }^{189}$ Under the doctrine of res ipsa loquitur-Latin for "the thing speaks for itself" 190 - the circumstances of an injury may raise the presumption of negligence against the defendant. ${ }^{191}$ Res ipsa loquitur shifts the burden to the defendant to prove that she was not negligent. ${ }^{192}$ To receive this inference, a plaintiff must prove (1) that the defendant had exclusive control of the dangerous instrumentality, (2) that the occurrence would not happen in the ordinary course of events absent some negligence, and (3) that the plaintiff did not contribute to the accident's occurrence. ${ }^{193}$

One court described res ipsa loquitur as "the creature of necessity" because "[i]t is imported into our jurisprudence to avoid a miscarriage of justice in those negligence cases in which the dangerous instrumentality is exclusively in the control of one charged with liability and in which there is secrecy or invisibility of the danger of which the outsider could know nothing." ${ }^{194}$ In this way, res ipsa loquitur overlaps with strict liability, which imposes liability without evidence of fault because accidents tend to destroy such evidence and victims often lack knowledge and control of the activity's riskiness. ${ }^{195}$ Some commentators and courts have found that res ipsa loquitur obviates the need for the strict liability doctrine. ${ }^{196}$ Some advocates of strict liability, however, find it an inadequate substitute ${ }^{197}$ because it is merely a procedural rule,

188. 1 Stuart M. Speiser, THE NEgLigenCE CASE: Res IPSA LoQuitur $§ 1: 9$ (1972).

189. Compare Boston, supra note 103, at 647 (noting that res ipsa loquitur obviates the need for strict liability), with Jones, supra note 157, 1735-36 (arguing that res ipsa loquitur, though an alternative to strict liability, is an inadequate one).

190. Clarence Morris \& C. Robert Morris JR., Morris on TORTS 117 (2d ed. 1980).

191. SPEISER, supra note 188, § 1:1; see also Byrne v. Boadle, (1863) 2 H \& C 722, 727-28 (establishing the res ipsa loquitur doctrine to compensate a plaintiff who could not prove that the defendant was negligent when his barrel of flour fell from a window and hit the plaintiff).

192. SPEISER, supra note 188 , § 1:1.

193. Id. § 2:1.

194. E. I. Du Pont De Nemours \& Co. v. Cudd, 176 F.2d 855, 857-58 (10th Cir. 1949).

195. See Jones, supra note 157, at 1735-36 (stating that "res ipsa [loquitur] tends to overlap with circumstances suggesting strict liability” particularly in cases of escape of water).

196. See Ind. Harbor Belt R.R. v. Am. Cyanamid Co., 916 F.2d 1174, 1178-79 (7th Cir. 1990) (arguing that a plaintiff could "overcome the destruction of the evidence" using res ipsa loquitur); Boston, supra note 103, at 647.

197. See, e.g., Jones, supra note 157 , at 1736 (“[R]es ipsa is a highly imperfect substitute for strict liability, which does not require an inference of negligence, on the part of defendant or anyone else, and is not subject to rebuttal or rejection except on the very limited grounds afforded by 
which a defendant may rebut by showing she was not negligent. ${ }^{198}$ Strict liability, on the other hand, is not rebuttable. ${ }^{199}$ As a practical matter, courts tend to apply res ipsa loquitur when they are not willing to embrace either strict liability or ordinary negligence. ${ }^{200}$

\section{ANALYSIS}

This Comment will now analyze whether fracking should be subject to strict liability for abnormally dangerous activities or, alternatively, whether a fault-based standard with a res ipsa loquitur rule is more appropriate. It will examine section 520 to determine whether fracking qualifies as an abnormally dangerous activity under the Second Restatement. Specifically, this section will compare application of each section 520 factor to fracking with application of that factor to analogous oil field activities. These activities are comparable to fracking with regard to their location, methods and materials, and purpose. Nonoilfield examples will supplement the discussion where oilfield cases do not exist to illustrate a particular point.

\section{A. Factors (a) and (b): High Degree of Risk of Great Harm}

1. Combined Analysis of Factors (a) and (b)

Courts tend to analyze the first two factors of section 520 together. ${ }^{201}$ Taken together, the factors require that the harm threatened "be major in degree, and sufficiently serious in its possible consequences to justify holding the defendant strictly responsible for subjecting others to an unusual risk. It is not enough that there is a recognizable risk of some relatively slight harm....,202 Further, “[i]f the potential harm is

\footnotetext{
specified defenses.”).

198. Id.

199. Id. at $1735-36$.

200. VANDALL, supra note 92, at 10.

201. See, e.g., Anderson v. Farmland Indus., 136 F. Supp. 2d 1192, 1198-99 (D. Kan. 2001) (analyzing factors (a) and (b) together under of the section 520 test); see also Yslava v. Hughes Aircraft Co., No. CIV-91-525-TUC-ROS, 1998 U.S. Dist. LEXIS 17228, at *4 (D. Ariz. June 26, 1998) ("The first two factors are substantially similar and both parties, as well as many courts, analyze these factors together. This court will do the same.”). The factors are so substantially similar that even the Restatement's comments analyze them together. See RESTATEMENT (SECOND) OF TORTS § $520 \mathrm{cmt}$. g (1977).

202. RESTATEMENT (SECOND) OF TORTS § $520 \mathrm{cmt}$. g.
} 
sufficiently great ..., [then] the likelihood that it will take place may be comparatively slight and yet the activity be regarded as abnormally dangerous." ${ }^{203}$ The Restatement's comment g cites a nuclear explosion as an example of a great harm. ${ }^{204}$ According to Professor Boston, factors (a) and (b), though not usually dispositive by themselves, tend to weigh more heavily in courts' applications of section $520 .^{205}$

\section{a. Great Harm}

Two Kansas cases discuss the great harm factor of section 520 in situations comparable to fracking. The district court in Anderson $v$. Farmland Industries, applying factors (a) and (b), held that an oil refinery was not abnormally dangerous. ${ }^{206}$ The plaintiffs in Anderson sued under a theory of strict liability for abnormally dangerous activities $^{207}$ and alleged that certain gases in the refinery's emissions posed human health risks when present in sufficient concentrations. ${ }^{208}$ The court disagreed. ${ }^{209}$ Noting that "some' harm” could result from the refinery's emissions, the Anderson court held that plaintiffs failed to show a "high degree of risk of [such] harm or that the harm [would] be great." 210

The Anderson plaintiffs suffered from two shortcomings. First, they could not show that the harmful gases complained of presented a high enough risk of harm. ${ }^{211}$ Second, though plaintiffs did submit evidence that the refinery's emissions frequently contained harmful gases, proof of frequency without proof of seriousness of the potential harm fails the factors (a) and (b) requirements. ${ }^{212}$

The decision in Anderson has an important implication for fracking's status under factors (a) and (b) - the fact that that frac fluid merely contains possibly harmful chemicals is likely insufficient to satisfy factors (a) and (b). For those chemicals to create a high degree of risk of

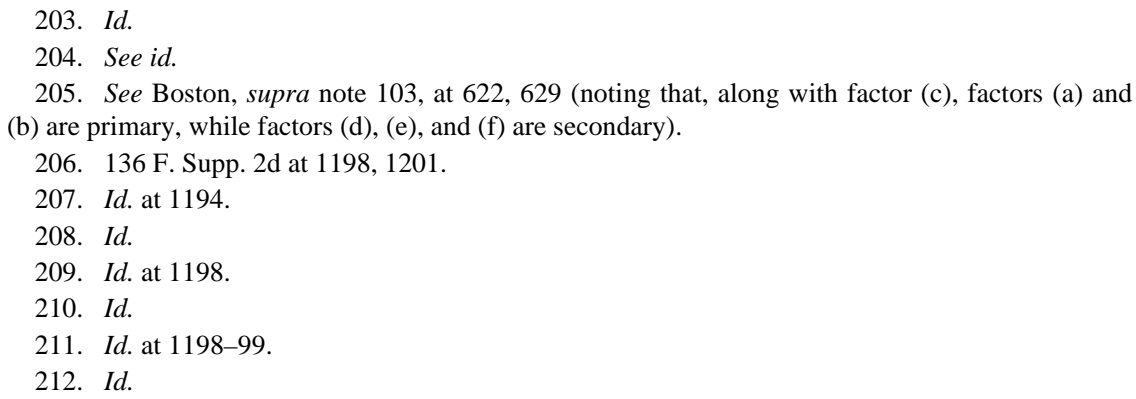


a great harm, they must exist in harmful concentrations in frac fluid. Frac fluid contains low, diluted concentrations of chemicals whose effects are further mitigated by dispersion, diffusion, adsorption, and biodegradation. ${ }^{213}$ Further, fracking operations actively retrieve released frac fluids ${ }^{214}$-a precaution that oil refineries do not take.

The Kansas Supreme Court also has held that a natural gas drilling operation does not pose a risk of significant harm to drinking water. ${ }^{215}$ In the 1987 case of Williams v. Amoco Production Co., a landowner sued a natural gas producer for leakage of natural gas into underground water supply. ${ }^{216}$ The plaintiff alleged that the natural gas had come from defendant's wells. ${ }^{217}$ In holding that the defendant was not strictly liable because natural gas production is not an abnormally dangerous activity, the Williams court accepted the defendant's argument that

natural gas... does not damage the fertility of the soil or growing crops; nor does it injure livestock or affect the quality of water. This is true because natural gas is in solution in the water until agitated and, upon reaching the surface, dissipates into the atmosphere. The presence of natural gas in the water-bearing aquifers has not resulted in an explosion, nor has it "polluted" nearby land or water . . . ${ }^{218}$

As in Anderson, the Williams court declined to hold that a substance benign in form and concentration creates risk of a great harm. ${ }^{219}$ Moreover, the natural gas held harmless in Williams is the very same that allegedly contaminates drinking water from fracking. ${ }^{220}$

\section{b. High Degree of Risk}

In a case arising in Arizona, one federal court refused to find a high degree of risk absent clear scientific evidence of a risk. ${ }^{221}$ In Yslava $v$.

\footnotetext{
213. EPA USDW EVALUATION 2004, supra note 33, at 4-3 to 4-4, 4-15 to 4-16.

214. Id. at 4-15.

215. Williams v. Amoco Prod. Co., 734 P.2d 1113, 1123 (Kan. 1987).

216. Id. at $1116-17$.

217. Id.

218. Id. at 1123.

219. Id.

220. See, e.g., Fiorentino v. Cabot Oil \& Gas Corp., 750 F. Supp. 2d 506, 509 (M.D. Pa. 2010) ("Plaintiffs allege that Defendants improperly conducted hydrofracturing and other natural gas production activities that allowed the release of methane, natural gas, and other toxins onto Plaintiffs' land and into their groundwater.” (footnote omitted) (emphasis added)).

221. See Yslava v. Hughes Aircraft Co., No. CIV-91-525-TUC-ROS, 1998 U.S. Dist. LEXIS 17228, at $* 9-10$ (D. Ariz. June 26, 1998) (holding that defendants were not on notice of
} 
Hughes Aircraft Co., the district court heard a strict liability claim by a group of residents against an aircraft manufacturer. ${ }^{222}$ The plaintiffs alleged that the defendant contaminated nearby groundwater by disposing of a solvent called trichloroethylene (TCE) directly onto the ground. ${ }^{23}$ Applying section 520 factors (a) and (b), the Yslava court held that defendant's activity did not create a high degree of risk of harm because the scientific community, at the time of the activity, believed that ground disposal of TCE was safe. ${ }^{224}$

A notion of fairness to the defendant appears to have informed the Yslava interpretation of factors (a) and (b). The court disposed of factors (a) and (b) in defendant's favor seemingly because defendant lacked notice from the scientific community that its activity created a high risk of harm. ${ }^{225}$ Nowhere does section 520 impose a notice requirement for strict liability. ${ }^{226}$ Indeed, it seems antithetical to the doctrine to let a defendant off the hook because it lacked knowledge of the risk caused by its activities. The case of fracking, however, reveals some wisdom in the Yslava court's application of factors (a) and (b). Like ground disposal of TCE in Yslava, prevailing science currently considers fracking safe. ${ }^{227}$ Whether and for how long that scientific paradigm will continue are open questions. $^{228}$ It would be unfair, however, to consider fracking abnormally dangerous as a matter of law when prevailing science has only very recently and preliminarily doubted its safety. When viewed this way, Yslava stands for the proposition that it is a matter of fairness that a defendant should be strictly liable for an activity that it has no reason to believe is harmful.

The first two factors of section 520 appear to weigh against

trichloroethylene's riskiness because contemporary prevailing science did not recognize that it was harmful to groundwater).

222. Id. at *1-2.

223. Id. at *1-2, 12-13.

224. Id. at *9-10; see also id. at *13-14 (referencing the affidavit of defendant's expert witness, who testified that placing TCE on the ground and letting it evaporate was considered safe disposal by the scientific community).

225. Id. at *9-10.

226. See generally RESTATEMENT (SECOND) OF TORTS $§ 520$ (1977).

227. See EPA USDW Evaluation 2004, supra note 33, 7-5 to 7-6 (concluding that no evidence links fracking operations to degradation of underground sources of drinking water).

228. The EPA's 2011 investigation of the Pavillion Gas Field has led the agency to believe some link probably exists between fracking and groundwater contamination. See EPA USDW EVALUATION DRAFT 2011, supra note 75 at 33, 39 (suggesting that shallow pits may be a source of contamination and calling for more research). Whether the theory can withstand criticisms of its validity remains to be seen. 
classifying fracking as an abnormally dangerous activity. Fracking probably does not threaten a great harm because, like emissions from an oil refinery, frac fluid does not contain harmful toxins in dangerous concentrations. Likewise, it seems unfair for a court to find that fracking poses a high degree of risk because scientific evidence-at the present, at least-has concluded that it does not.

\section{Factor (e): Inappropriateness of the Activity to Its Location}

The authors of the comments to section 520 and many courts examine factors (a) and (b) in conjunction with factor (e)-the inappropriateness of the activity to its location. ${ }^{229}$ The authors apparently intended factor (e) to consider whether an activity constitutes a "natural use" of the land where it is conducted. ${ }^{230}$ The rationale for considering factors (a) and (b) with factor (e) is that certain activities are risky only when conducted in certain locations. ${ }^{231}$ For example, a large water reservoir in open country is not abnormally dangerous, but the same reservoir on a bluff above a large city is. ${ }^{232}$ In short, courts cannot determine the degree of risk of great harm of an activity in the abstract, but rather they must consider the risk in the context of its location.

Courts nationwide have held that the operation of oil and gas wells in oil and gas fields is not abnormally dangerous. ${ }^{233}$ That was the result in Williams. $^{234}$ The plaintiffs in Williams were landowners in the Hugoton Natural Gas Field of western Kansas. ${ }^{235}$ Their argument that defendant's natural gas production was abnormally dangerous ${ }^{236}$ failed because "the drilling and operation of natural gas wells in [a gas field] is a common, accepted, and natural use of the land."237 The Williams holding is

229. See RESTATEMENT (SECOND) OF TORTS $\S 520 \mathrm{cmt}$. g.

230. See id. $\S 520 \mathrm{cmt}$. j ("This [factor] is sometimes expressed, particularly in the English cases, by saying there is strict liability for a 'non-natural' use of the defendant's land.”).

231. Id. § $520 \mathrm{cmt}$. g.

232. Id. §520 cmt. j.

233. E.g., Williams v. Amoco Prod. Co., 734 P.2d 1113, 1123 (Kan. 1987) (holding that "the drilling and operation of natural gas well is not an abnormally dangerous activity"); Charles F. Hayes \& Assocs., Inc. v. Blue, 233 So.2d 127, 128 (Miss. 1970) (requiring proof of negligence to impose liability for damage caused by oil field drilling operations).

234. 734 P.2d at 1123.

235. Id. at 1116. "The Hugoton field is the largest natural gas field in North America ...." Tim Carr \& Robert S. Sawin, Hugoton Natural Gas Area of Kansas, KAN. GeOlOGICAL Survey, http://www.kgs.ku.edu/Publications/pic5/pic5_1.html (last visited Apr. 4, 2012).

236. Williams, 734 P.2d at 1121.

237. Id. at 1123. 
comparable to other, non-oil field cases. For instance, a district court in Kansas has held that manufacturing activities that use the chemical TCE - known at the time of the case to be dangerous-are appropriately located in industrial zones. ${ }^{238}$

It is more contentious whether petroleum activities, like fracking, are abnormally dangerous when conducted near populated areas and aquifers. Courts have answered this question in the context of petroleum storage tanks, such as those that hold gasoline under service stations. Though generally not held to be abnormally dangerous, ${ }^{239}$ gasoline tanks may become so when located near drinking water sources that serve population centers. ${ }^{240}$ Such was the 1993 case of Harthman v. Texaco, Inc., in which the court held that the underground storage of gasoline for a fuel station was abnormally dangerous because of the storage tanks' location. ${ }^{241}$ The fuel station's tanks were situated directly above a fresh water aquifer that served as the community's primary drinking water. ${ }^{242}$ The precarious location of the storage tanks was enough to increase the likelihood of harm, and make the potential for harm great, where it otherwise might not have been. ${ }^{243}$

The common thread running through these cases is how location of an activity affects its riskiness. It seems that when a petroleum-related activity occurs away from populations-and the aquifers from which those populations draw water-it is not abnormally dangerous. Today, fracking, like the gas production at issue in Williams, typically happens in remote or rural areas, far from the drinking water sources of large populations. $^{244}$ It follows that fracking does not create a high degree of risk of great harm when conducted in such an area. The revolution of unconventional gas discoveries in states like New York and Pennsylvania, however, has opened up unproduced gas fields in areas of

238. Greene v. Prod. Mfg. Corp., 842 F. Supp. 1321, 1327 (D. Kan. 1993).

239. See, e.g., Hahn v. Chevron, U.S.A., Inc., No. 94-5466, 1995 U.S. App. LEXIS 17528, at *1-2 (6th Cir. July 5, 1995) (affirming district court's holding that Kentucky courts would not apply strict liability to the storage of gasoline); Arlington Forest Assocs. v. Exxon Corp., 774 F. Supp. 387, 388 (E.D. Va. 1991) ("[S]torage and removal of gasoline in underground tanks is not an abnormally dangerous activity for which common law strict liability should be imposed.”); Hudson v. Peavey Oil Co., 566 P.2d 175, 177-78 (Or. 1977) (same); Smith v. Weaver, 665 A.2d 1215, 1220 (Pa. Super. Ct. 1995) (same).

240. See, e.g., Harthman v. Texas, Inc., 846 F. Supp. 1243, 1270 (D.V.I. 1993).

241. Id.

242. Id. at 1269 .

243. Id. at 1270 .

244. See, e.g., EPA USDW EVALUATION DRAFT 2011, supra note 75, at 1 (discussing fracking operations in Pavillion, Wyoming). 
denser population than western Kansas. ${ }^{245}$ The question is whether fracking in these new fields is appropriate, as it likely would be in the Hugoton field.

At first glance, it would seem that if fracking occurs near populations and adjacent to an important aquifer-like the underground gasoline storage in Harthman - it might be likelier to cause a greater harm than if it were otherwise located. The same could be said of fracking near water wells and surface water sources; perhaps, it even could be extended to underground plumbing. It follows, then, that fracking would be appropriate in gas fields where no aquifers, streams, ponds, water wells, plumbing, or the like exist. In other words, fracking may occur where no people live and draw water. Under this view, practically no appropriate place would exist for fracking; however, the gasoline tanks in Harthman are distinguishable from the activity of fracking. The issue of the gas storage tanks' proximity to the community's aquifer in Harthman is highly improbable in a fracking case. Unlike the storage of underground gasoline tanks in Harthman, fracking occurs in underground formations that are isolated from aquifers by thousands of feet of formation rock. ${ }^{246}$ Although sometimes performed in the same gas field as an aquifer, fracking is much less likely to contaminate the water source than the storage tanks in Harthman.

But, assuming a court did find that fracking near an aquifer increased its risk of great harm, that finding might not dispose of the abnormally dangerous question. ${ }^{247}$ In Smith $v$. Weaver, the Pennsylvania appellate court found in 1995 that because of an underground storage tank's location, it could cause great harm if the tank leaked. ${ }^{248}$ The Smith court, however, held that the activity was not abnormally dangerous, stating that "this one factor pales in comparison to the others [that] point in favor of our ruling that the storage of petroleum products in underground storage tanks is not abnormally dangerous."249 As stated above, inappropriateness of the activity's location is a mere factor, not an element, in the section 520 test.

245. Greene, supra note 4.

246. ARTHUR, BoHM \& LAYNE, supra note 49, at 2. It is also true that coalbed methane fracking occurs at much shallower depths and often directly into an underground drinking water source. EPA USDW EVALUATION DRAFT 2011, supra note 75, at 39. This makes fracking much more comparable to the tanks in Harthman and possibly reverses the result of this analysis.

247. Smith v. Weaver, 665 A.2d 1215, 1220 (Pa. Super. Ct. 1995).

248. Id.

249. Id. 
In sum, factors (a) and (b) - the high risk of a great harm-seem to weigh against fracking's qualifying as abnormally dangerous because the dangerous chemicals in frac fluid are significantly diluted and prevailing science still considers fracking a safe practice. Factor (e), on the other hand, favors holding fracking operators strictly liable when it occurs near populations and their sources of water.

\section{B. Factor (c): Risk Not Eliminated by Reasonable Care}

To apply factor (c) to fracking, this section will propose a definition of fracking, which has proved to be the threshold question in factor (c) analyses. ${ }^{250}$ It will then examine how courts should apply factor (c) to fracking by analogizing it to comparable oil and gas activities that courts have analyzed. Finally, this section will discuss how res ipsa loquitur operates in cases of avoidable accidents and, specifically, how it should operate in a fracking case.

\section{Explanation of Factor (c)}

According to Professor Boston, factor (c) is the most important of the section 520 factors. $^{251}$ This factor tends to be outcome-determinative in strict liability cases. ${ }^{252}$ The body of strict liability law as applied to oil field operations appears to corroborate that assertion. Factor (c) refers to "the unavoidable risk remaining in the activity, even though the actor has taken all reasonable precautions in advance and has exercised all reasonable care in his operation, so that he is not negligent." ${ }^{253}$ In application, according to Professor Boston, courts hold an activity abnormally dangerous only when the residual risk is high or abnormal. ${ }^{254}$ In essence, factor (c) examines whether accidents are avoidable or not.

250. See Boston, supra note 103, at 649 (“[H]ow the 'activity' being evaluated is described by the court will greatly influence the outcome of the analysis under section 520.”).

251. See id. at 629 (arguing that factor (c) is often dispositive).

252. Id. Put another way, "when this factor weighs in favor of applying strict liability, the courts will generally apply strict liability." Id.

253. RESTATEMENT (SECOND) OF TORTS § $520 \mathrm{cmt}$. h (1977).

254. Boston, supra note 103, at 639; see also New Meadows Holding Co. v. Wash. Water Power Co., 687 P.2d 212, 216 (Wash. 1984) (en banc) (finding that reasonable care could reduce the risk associated with a natural gas line to prevent the application of strict liability). 
2. Defining the Activity at Issue

How courts define the activity at issue is the threshold question in factor (c) analyses. ${ }^{255}$ The more generally a court describes an activity, the more likely it is to find that reasonable care can eliminate the activity's high risk. ${ }^{256}$ Professor Boston notes that many courts define an activity in its "benign, pre-injury-causing condition" to avoid applying strict liability. ${ }^{257}$ In 1995, one Pennsylvania state court explained the task of framing an activity in similar terms:

The [plaintiffs] would urge us to consider not whether underground tanks are abnormally dangerous, but rather whether underground storage tanks [that] are leaking a hazardous substance, are abnormally dangerous. By so phrasing the issue the [plaintiffs] are seeking to have us view the results of the activity, instead of the activity itself. Although a dangerous condition may have later developed, or harm may have occurred, the proper focus is on the activity itself . . . . ${ }^{258}$

Courts that define an activity by the harm it already has caused cannot help but weigh factor (c) in favor of strict liability. Take, for example, the 1983 New Jersey Supreme Court case of State Department of Environmental Protection v. Ventron Corp. ${ }^{259}$ In its application of factor (c), the Ventron court found only "[w]ith respect to the ability to eliminate the risks involved in disposing of hazardous wastes by the exercise of reasonable care, no safe way exists to dispose of mercury by simply dumping it onto land or into water."260 The Ventron court could have defined the activity in its pre-accident phase as "disposing of mercury." Instead, Ventron chose the narrower definition, making its decision that the activity was abnormally dangerous seem predetermined.

Drawing the distinction between dangerous substances and a dangerous activity has been problematic for courts trying to define activities. In the 1990 case of Indiana Harbor Belt Railroad v. American Cyanamid Co., the Seventh Circuit observed that "ultrahazardousness or abnormal dangerousness is, in the contemplation of the law at least, a

255. See supra note 250 and accompanying text.

256. See Boston, supra note 103, at 649 ("By defining the activity at the greatest level of generality, the probability of finding strict liability is reduced.”).

257. Id. at 652 .

258. Smith v. Weaver, 665 A.2d 1215, 1219 (Pa. Super. Ct. 1995) (emphasis added).

259. 468 A.2d 150 (N.J. 1983).

260. Id. 
property not of substances, but of activities .... Natural gas is both flammable and poisonous, but the operation of a natural gas well is not an ultrahazardous activity."261 In 1983, an Indiana state court in Erbrich Products Co. v. Wills explicitly separated the dangerousness of chlorine gas from the dangerousness of manufacturing bleach from chlorine. ${ }^{262}$ The plaintiffs in Erbrich sued a liquid bleach manufacturer under a theory of strict liability for abnormally dangerous activity for accidentally releasing a harmful amount of chlorine gas into the surrounding outside air. ${ }^{263}$ The plaintiffs urged the court to examine the dangerous characteristics of chlorine gas. ${ }^{264}$ Where the Ventron court might have framed the issue as whether the release of chlorine gas into the air is abnormally dangerous, the Erbrich court defined it more broadly as "[w]hether the manufacture of chlorine bleach constitutes an ultra-hazardous or abnormally dangerous activity."265 The Erbrich court noted that if it were to analyze the properties of the dangerous substance instead of the activity itself, then "any commercial or industrial activity involving substances [that] are dangerous only in the abstract automatically would be deemed as abnormally dangerous. This result would be intolerable."266 After analyzing the defendant's manufacturing activities, the Erbrich court found that due care could have eliminated the risks of chlorine gas pollution. ${ }^{267}$ Put another way, it was an avoidable accident. This result was no surprise because the defendant had been manufacturing bleach by the same basic methods without incident for over fifty years. ${ }^{268}$

\section{Factor (c) Applications in Oil and Gas Cases}

This section will discuss whether due care can eliminate fracking's risk of great harm. It will examine this question in the context of analogous oil and gas production activities. Petroleum drilling,

261. Ind. Harbor Belt R.R. v. Am. Cyanamid Co., 916 F.2d 1174, 1181 (7th Cir. 1990) (citations omitted) (citing Cropper v. Rego Distrib. Ctr., Inc., 542 F. Supp. 1142, 1149 (D. Del. 1982); Williams v. Amoco Prod. Co., 734 P.2d 1113, 1123 (Kan. 1987)).

262. See 509 N.E.2d 850, 856 (Ind. Ct. App. 1987) ("We hold that the manufacture of liquid household bleach using chlorine gas is not an abnormally dangerous activity.”).

263. Id. at 852.

264. Id. at 856 .

265. Id. at 853 .

266. Id. at 856 .

267. Id.

268. Id. at 852 . 
servicing, transportation, storage, waste disposal, and waterflooding tend to occur in the same areas as fracking, require similar instruments, materials, and methods, and rely on the same actors. ${ }^{269}$ Also, the potential harms of these activities ${ }^{270}$ are comparable to those of fracking. ${ }^{271}$

\section{a. Well Drilling and Servicing}

Courts generally find that due care can eliminate the high risk of harm from drilling and servicing gas wells. ${ }^{272}$ Even jurisdictions that have called drilling gas wells an ultrahazardous activity apply a "reasonable care under all the circumstances" standard, rather than strict liability, to the activity. ${ }^{273}$ In 1991, a district court in Mississippi found that due care can eliminate the high risk of well servicing or "workover" activities. ${ }^{274}$ Plaintiffs sued after a defendant's well blew out ${ }^{275}$ during a workover $^{276}$ operation. ${ }^{277}$ The plaintiffs claimed that defendants should be strictly liable because workover operations are abnormally dangerous. ${ }^{278}$ The court gave this argument short shrift. Noting that

269. See infra Part III.B.3.

270. For a description of the harms alleged in cases of petroleum well drilling and servicing, transportation, storage, waste disposal, and waterflooding, see infra Part III.B.3.

271. See, e.g., Berish v. Sw. Energy Prod. Co., 763 F. Supp. 2d 702, 704 (M.D. Pa. 2011) (summarizing fracking plaintiffs' allegations that "pollutants and other industrial waste, including the fracking fluid and other hazardous chemicals such as barium and strontium, were discharged into the ground and contaminated the [plaintiff's] water supply"); Fiorentino v. Cabot Oil \& Gas Corp., 750 F. Supp. 2d 506, 509 (M.D. Pa. 2010) (describing the plaintiffs' claims that the drilling operation "improperly conducted hydrofracturing and other natural gas production activities that allowed the release of methane, natural gas, and other toxins onto their land and into their groundwater." (footnote omitted)).

272. E.g., Williams v. Amoco Prod. Co., 734 P.2d 1113, 1123 (Kan. 1987) (holding that "the drilling and operation of natural gas wells is not an abnormally dangerous activity"); Charles F. Hayes \& Assocs., Inc. v. Blue, 233 So.2d 127, 128 (Miss. 1970) (requiring proof of negligence to impose liability for damage caused by oilfield drilling operations).

273. See, e.g., Hull v. Chevron U.S.A., Inc., 812 F.2d 584, 589 (10th Cir. 1987) (applying Wyoming law).

274. Bolivar v. R \& H Oil \& Gas Co., 789 F. Supp. 1374, 1383 (S.D. Miss. 1991).

275. A well blowout is "[a]n uncontrolled flow of reservoir fluids into the wellbore, and sometimes catastrophically to the surface. A blowout may consist of salt water, oil, gas or a mixture of these.” Blowout, SCHLUMBERGER Oilfield Glossary (last visited Apr. 22, 2012), http://www.glossary.oilfield.slb.com/Display.cfm?Term=blowout.

276. A workover is "[t]he process of performing major maintenance or remedial treatments on an oil or gas well.” Workover, SCHLUMBERGER OILFIELD GLOSSARY (last visited Apr. 22, 2012), http://www.glossary.oilfield.slb.com/search.cfm?Term=workover.

277. Bolivar, 789 F. Supp. at 1375.

278. Id. at 1382. 
workovers occur daily without incident and that sophisticated safety equipment significantly reduces the frequency of accidents, the court found that due care could — and did — eliminate the risk of blowouts from workovers. ${ }^{279}$

\section{b. Natural Gas Transportation}

Pipeline transportation of natural gas has given rise to numerous claims for strict liability for abnormally dangerous activities. Those claims often fail because of factor (c) - the ability to reduce harm through exercise of reasonable care. ${ }^{280}$ Courts tend to apply negligence instead of strict liability in gas transportation cases. ${ }^{281}$ For instance, in Mahowald v. Minnesota Gas Co., the Minnesota Supreme Court declined to hold a defendant gas transporter strictly liable because natural gas does not escape and cause harm in the ordinary course of its transportation through a pipeline. ${ }^{282}$ The Mahowald court's inference here, apparently, is that when conducted with due care, pipeline transportation of natural gas is not highly risky.

\section{c. Petroleum Storage}

Courts tend to find that the exercise of reasonable care can eliminate the risks of pollution from petroleum storage tanks. ${ }^{283}$ Cases of this type

\footnotetext{
279. Id. at 1383 \& n.15.
}

280. See Fletcher v. Conoco Pipe Line Co., 129 F. Supp. 2d 1255, 1261 (W.D. Mo. 2001) ("[T]he operation and cathodic protection of a petroleum pipeline is a routine and easily regulated activity.”); Mahowald v. Minn. Gas Co., 344 N.W.2d 856, 863 (Minn. 1984) (en banc) (applying a negligence standard to gas pipelines, but creating a rebuttable presumption of negligence under res ipsa loquitur, because escape and explosion of gas does not happen in the ordinary course of the activity absent some fault); New Meadows Holding Co. v. Wash. Water Power Co., 687 P.2d 212, 216 (Wash. 1984) (en banc) ("[W]e believe the high degree of risk involved in the transmission of natural gas through underground lines can be eliminated by the use of reasonable care and legislative safeguards.”). The courts in New Meadows and Mahowald cite numerous cases that applied negligence rather than strict liability to gas pipelines. See New Meadows, 687 P.2d at 215; Mahowald, 344 N.W.2d at 861.

281. Mahowald, 344 N.W.2d at 861, 863.

282. Id. at 863 .

283. See Arlington Forest Assocs. v. Exxon Corp., 774 F. Supp. 387, 390-91 (E.D. Va. 1991) ("Maintained, monitored, and used with due care, underground gasoline storage tanks present virtually no risk of injury from seepage of their contents.”); Hudson v. Peavey Oil Co., 566 P.2d 175, 178 (Or. 1977) ("[W]e cannot hold ... that the risk of seepage cannot be eliminated by the exercise of reasonable care ....”); Smith v. Weaver, 665 A.2d 1215, 1220 (Pa. Super. Ct. 1995) ("Applying these [section 520] factors to the situation before us, we conclude that the operation of underground storage tanks at a gasoline service station is not an abnormally dangerous activity.”). 
often refer to the commonness of gasoline storage tanks as a reason not to apply strict liability. ${ }^{284}$ Though commonness of the activity is a separate factor in section $520,{ }^{285}$ its frequent inclusion in petroleum storage cases has an important implication for factor (c) applications: an activity's combination of commonness and infrequency of accidents implies that reasonable care can eliminate the activity's riskiness. Storage tanks are quite common and do not frequently contaminate the environment; they are, therefore, generally not held to be abnormally dangerous.

\section{d. Disposal Wells and Waterfloods}

Courts seem willing to apply strict liability in cases involving disposal wells and waterfloods. ${ }^{286}$ Disposal wells are those in which oilfield waste, such as saltwater, is pumped or injected into underground formations. ${ }^{287}$ Waterflooding is a method of secondary oil recovery in which injection wells "flood" oil-bearing formations with water to sweep residual oil into the well. ${ }^{288}$ The complaints in these cases arise from saltwater and crude oil contamination of fresh water sources. ${ }^{289}$ As one court explained, these operations continually force water "through more porous rock and earth formations" and into fresh water aquifers. ${ }^{290}$ The continuous introduction of wastewater into formations with high permeability appears to focus courts on the high risk that waste and crude oil could migrate into fresh water reserves. Because this high risk seems

284. See, e.g., Arlington Forest Assocs., 774 F. Supp. at 391 (“[T]he presence and use of filling stations in and near residential areas is widespread and routine. In fact, filling stations with underground tanks are commonplace in most communities throughout the country.”); Smith, 665 A.2d at 1220 (noting that gasoline storage tanks are common in modern society).

285. See infra Part III.C (discussing factor (d), the commonness of usage factor).

286. See, e.g., Mowrer v. Ashland Oil \& Ref. Co., 518 F.2d 659, 662 (7th Cir. 1975) ("The waterflood ... introduced a risk of serious harm to the land of others [that] could not be eliminated by the exercise of care ....”); Gulf Oil Corp. v. Hughes, 371 P.2d 81, 82, 84 (Okla. 1962) (affirming jury instructions for strict liability for waterflooding).

287. Disposal Well, Schlumberger Oilfield Glossary (last visited Apr. 22, 2012), http://www.glossary.oilfield.slb.com/search.cfm?Term=disposal\%20well. "Disposal wells typically are subject to regulatory requirements to avoid the contamination of freshwater aquifers.” Id.

288. Waterflood, SChlumberger OILFIELD Glossary (last visited Apr. 22, 2012), http://www.glossary.oilfield.slb.com/search.cfm?Term=waterflood.

289. See, e.g., Mowrer, 518 F.2d at 661 (describing plaintiff's complaint that "crude oil leaked into and contaminated the nearby fresh water well that supplied plaintiff's domestic water"); Hughes, 371 P.2d at 82 (outlining the plaintiff's allegation that as a result of defendant's waterflood project saltwater polluted plaintiff's drinking water).

290. Hughes, 371 P.2d at 82. 
unavoidable given the continuous nature of the activities and the high porosity of the rock formations involved, courts often conclude that waterflood projects and disposal wells are abnormally dangerous. ${ }^{291}$

\section{Application of Factor (c) to Fracking}

This subsection will apply factor (c) to fracking first by proposing a definition of fracking. Following Professor Boston's advice to courts, the definition should focus on fracking's benign, pre-accident phase: the pressurized injection of frac fluid into deep, dense subsurface rock formations-or simply, as the hydraulic fracturing of geologic formations. In the context of factor (c), fracking appears to be more analogous to petroleum servicing, storage, and transportation than to waterflooding and disposal. Unlike waterflooding and disposal operations, fracking likely is not unavoidably risky. Whereas waterfloods and disposal wells continually pump contaminants underground, fracking is an occasional act. Further, waterfloods and disposals intentionally inject wastewater into geologic formations with high permeability and porosity through which fluid migration is relatively free. On the other hand, fracking occurs in very dense formations with low permeability through which fluid migration is constrained. Therefore, the qualities that make waterflooding and disposal wells unavoidably harmful do not appear to exist in fracking operations.

The common trait among petroleum drilling, servicing, storage, and transportation-which courts tend to find safe when conducted with reasonable care $^{292}$ - is that they are performed frequently and nearly always without incident. Fracking is no different. Like the workovers described in Bolivar, ${ }^{293}$ fracking is a daily occurrence in the oil and gas industry. And yet, like gas pipeline and storage tank accidents, fraccidents that contaminate drinking water occur infrequently. ${ }^{294}$ Additionally, courts' inferences about storage tanks, gas pipelines, and gas well drilling and servicing operations could apply to fracking as well:

291. E.g., Mowrer, 518 F.2d at 662.

292. See supra Part III.B.3 (reviewing holdings that drilling, operating, servicing, transportation, and storage activities are made safe when conducted with reasonable care).

293. Bolivar v. R \& H Oil \& Gas Co., 789 F. Supp. 1374, 1375 (S.D. Miss. 1991).

294. EPA USDW EVALUATION 2004, supra note 33, at 7-6. The EPA has theorized, however, that groundwater contamination in Wyoming's Pavillion Gas Field was caused by fracking operations. EPA USDW EVALUATION DRAFT 2011, supra note 75, at 39. 
its frequent occurrence and nearly impeccable safety history imply that the exercise of reasonable care can eliminate fracking's riskiness.

\section{Res Ipsa Loquitur in Cases of Avoidable and Unavoidable Oilfield Accidents}

When faced with a petroleum-related activity that is safe when conducted with due care, some courts apply res ipsa loquitur instead of strict liability. ${ }^{295}$ One such case involved a house explosion caused by a natural gas pipeline leak. ${ }^{296}$ In Mahowald v. Minnesota Gas Co., the Minnesota Supreme Court held that the trial court committed reversible error when it refused to give a res ipsa loquitur instruction, even though the plaintiffs claimed strict liability. ${ }^{297}$ The plaintiffs in Mahowald argued on appeal that the defendant, a natural gas distributor, should be held strictly liable because of the dangerous nature of gas transportation operations. ${ }^{298}$ The Mahowald court disagreed because "[i]n the ordinary course of events, natural gas does not escape from gas mains in public streets so as to cause explosion.”299 The court stated that res ipsa loquitur was justified because the defendant had superior knowledge of the gas system, access to the individual actors involved with the system, inspection and control over the system, and responsibility for the safety of the surrounding community. ${ }^{300}$ In sum, the court thought that res ipsa loquitur better served equity. ${ }^{301}$

In 1949, the Tenth Circuit analyzed res ipsa loquitur in the context of well shooting in E. I. Du Pont De Nemours \& Co. v. Cudd. ${ }^{302}$ A predecessor of fracking, well shooting was a technique for enhanced oil recovery in which producers exploded nitroglycerin at the bottoms of wells to free trapped oil. ${ }^{303}$ Well shooting was notoriously dangerous. ${ }^{304}$

295. See, e.g., Mahowald v. Minn. Gas Co., 344 N.W.2d 856, 863 (Minn. 1984) (en banc) (noting that res ipsa loquitur is appropriate in natural gas pipeline cases despite plaintiff's claims for strict liability); see also E. I. Du Pont De Nemours \& Co. v. Cudd, 176 F.2d 855, 858-59 (10th Cir. 1949) (noting that res ipsa loquitur would apply to this well-shooting case but for the fact that defendant did not have exclusive control of the dangerous instrumentality).

296. Mahowald, 344 N.W.2d at 858.

297. Id. at 858,864 .

298. Id. at 859 .

299. Id. at 863.

300. Id. (citing Metz v. Cont. Ill. Elec. \& Gas Co., 207 N.E.2d 305, 308 (Ill. 1965)).

301. Id. at 859 .

302. 176 F.2d 855, 856 (10th Cir. 1949).

303. HYNE, supra note 7, at 422-23. Well shooting was astoundingly effective, but just as dangerous. HOWARD \& FAST, supra note 19, at 5. By 1950, hydraulic fracturing had replaced 
The Tenth Circuit found res ipsa loquitur to be inapplicable to well shooting partly because "the [accident] was not so uncommon or unusual that it could be said that it must have been the result of negligence."305 Res ipsa loquitur was not a proper standard for analyzing well shooting because the activity caused frequent accidents; in other words, well shooting was unavoidably risky.

Res ipsa loquitur could be appropriate for fracking if the activity is held to be harmless in the ordinary course of events. Certainly there is no evidence that fraccidents are as commonplace as well shooting accidents. ${ }^{306}$ If fraccidents are held to be avoidable, like gas pipeline accidents have been, then equity would seem to require a fault-based standard in fracking cases. Furthermore, like the gas distributor in Mahowald, fracking defendants inspect and control-and otherwise possess superior knowledge of, access to, and responsibility for-their fracking operations. The result is that plaintiffs in fracking cases lack knowledge and control, which could justify application of res ipsa loquitur. Basically, the doctrine could avoid a harsh result for plaintiffs by imposing the burden of proof on the party with superior knowledgethe fracking operator.

\section{Factor (d): Extent to Which the Activity is Not a Matter of Common Usage}

Factors (d), (e), and (f) - the extent to which the activity is not common, the inappropriateness of the activity's location, and the extent to which the activity's value to the community is outweighed by its dangerousness, respectively-are difficult to analyze individually and, according to Professor Boston, are rarely outcome-determinative. ${ }^{307}$ Factor (d), in particular, tends to have a broad definition, which could diminish its usefulness to courts. Section 520 of the Second Restatement considers an activity to be a matter of common usage "if it is customarily carried on by the great mass of mankind or by many people in the community." 308 Comment i of section 520 uses the operation of oil wells

\footnotetext{
explosive fracturing as the preferred method of stimulation. Id.

304. HYNE, supra note 7, at 424.

305. Cudd, 176 F.2d at 858.

306. See EPA USDW EVALUATION 2004, supra note 33, at 7-5 (concluding that fracking is not sufficiently dangerous to warrant further study).

307. Boston, supra note 103, at 629.

308. See RESTATEMENT (SECOND) OF TORTS $§ 520$ cmt. i (1977).
} 
as an example of an activity that is not a matter of common usage. ${ }^{309}$ The example specifies that "the dangers incident to the operation are characteristic of oil lands and not of lands in general."310 Certainly, oil operations are not customarily carried on by the great mass of mankind, either.

Courts seem to stray from the Restatement's guidance when applying factor (d). Rather than compare the activity to the actions of "the great mass of mankind" or "lands in general" to determine commonness of usage, courts often compare the activity to what others in the same industry and vicinity do. The Fifth Circuit compared an activity in such a way in Sprankle v. Bower Ammonia \& Chemical Co. ${ }^{311}$ There, the court decided that the storage of the fertilizer anhydrous ammonia was not abnormally dangerous. ${ }^{312}$ Sprankle held that "since anhydrous ammonia is commonly used in a wide variety of agricultural, industrial, and commercial applications, its storage, even in large quantities, can hardly be said to be 'not a matter of common usage.",313 There, anhydrous ammonia's use in agricultural, industrial, and commercial contexts was sufficient to make it a matter of common usage under factor (d). ${ }^{314}$ Similarly, the court in Williams v. Amoco Production Co.discussed above in reference to an activity's great harm ${ }^{315}$ —held that the drilling and operation of natural gas wells was a matter of common usage because it occurred in an established gas field where other similar activities were common. ${ }^{316}$ Neither court considered whether the activity was common to all mankind.

Of course, most of the world's people do not frac. Fracking, however, is much more common in particular industrial and commercial contexts. $^{317}$ Just as in Sprankle, where the court held anhydrous ammonia to be common within the meaning of factor (d) because of its wide agricultural use, ${ }^{318}$ courts could consider fracking to be common because of its wide oilfield use. Likewise, fracking occurs in oil and gas

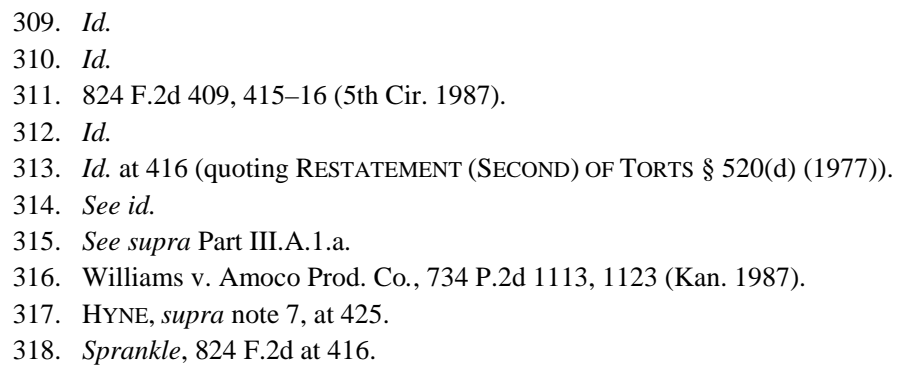


fields, just like the gas drilling that the Williams court found to be common under factor (d). ${ }^{319}$ Even though fracking is by no means "common to all mankind," courts could reasonably find that it is common within the meaning of factor (d).

\section{Factor ( $f$ ): Extent to Which the Activity's Value to the Community Is Outweighed by Its Dangerous Attributes}

Factor (f) - the extent to which the activity's value to the community is outweighed by its dangerous attributes - is the most maligned factor in section 520. ${ }^{320}$ Chief among its critics is Professor Page Keeton, reviser of Dean Prosser's treatise on torts. ${ }^{321}$ Professor Keeton believes factor (f) is "irrelevant on whether or not a risk should be allocated to the defendant because of the dangerousness, as such, of the activity." 322 Other writers and courts agree, and the factor is often not determinative of whether an activity is abnormally dangerous. ${ }^{323}$

The Restatement describes factor (f) as follows:

Even though the activity involves a serious risk of harm that cannot be eliminated with reasonable care and is not a matter of common usage, its value to the community may be such that the danger will not be regarded as an abnormal one. This is true particularly when the community is largely devoted to the dangerous enterprise and its prosperity largely depends upon it. ${ }^{324}$

The Restatement's comment $\mathrm{k}$ explains that oil or gas wells are not abnormally dangerous in Texas and Oklahoma, but they are abnormally dangerous in states that are less economically reliant upon the petroleum industry. ${ }^{325}$

Courts tend to interpret "value to the community" to mean the potential to create jobs. ${ }^{326}$ Anderson v. Farmland Industries held that an

\footnotetext{
319. Williams, 734 P.2d at 1123.

320. Boston, supra note 103, at 623-24, 627.

321. Id. at 627.

322. KeETON ET AL., supra note 93, § 78, at 555.

323. See Boston, supra note 103, at 629 (arguing "that factor (f) is not [appropriate for inclusion in the adjudicatory calculus]; and that, on examination, the decisions in the last thirty years support precisely that conclusion").

324. RESTATEMENT (SECOND) OF TORTS $§ 520 \mathrm{cmt}$. k (1977) (emphasis added).

325. Id.

326. See, e.g., Anderson v. Farmland Indus., Inc., 136 F. Supp. 2d 1192, 1201 (D. Kan. 2001) (discussing the significance of the jobs created by the refining activity when deciding whether it is
} 
oil refinery's value to the community outweighed its dangerousness, in part, because the refinery directly employed 325 people and indirectlythrough other companies that depended on the refinery's businessemployed another 100. ${ }^{327}$ Likewise, in Greene v. Product Manufacturing Corp., the Court held that a metal fabrication company's manufacturing activities benefited the community enough to justify its dangerous attributes. ${ }^{328}$ There, the court deemed the activity justified because metal fabrication was a necessary part of the aviation industry, which employed tens of thousands of workers in the community. ${ }^{329}$

Insofar as value to a particular community means the potential to create jobs, fracking's value is indisputably high. A Pennsylvania newspaper reported that fracking created as many as 72,000 new jobs in that state in two years. ${ }^{330}$ The result was an increase in the state's coffers of nearly one billion dollars. ${ }^{331}$ Measured indirectly, as in Greene and Anderson, fracking's employment impact would likely be greater. Though factor (f)'s relevance might be dubious, it probably weighs in fracking's favor if it weighs at all.

\section{CONCLUSION}

Fraccidents that cause environmental contamination should not be held unavoidable as a matter of law. Fracking has been a common occurrence in the oil and gas industry for over half a century. ${ }^{332}$ Yet, the EPA's own study of the issue has been unable to definitively prove a link between fracking and water pollution-at least for the present time. ${ }^{333}$ As the cases show, an activity that happens frequently but causes harm very infrequently is not abnormally dangerous; due care can eliminate such activity's potential for harm. It would be inequitable to hold an

\footnotetext{
an abnormally dangerous activity).

327. Id.

328. 842 F. Supp. 1321, 1327 (D. Kan. 1993).

329. Id.

330. Sam Shawver, Perspectives: Expansion of Oil, Gas Industry Could Mean More Jobs, MARIETTA TIMES (Sept. 17, 2011), http://www.mariettatimes.com/page/content.detail/id/538695/ Perspectives\%E2\%80\%94Expansion-of-oil\%E2\%80\%94gas-industry-could-mean-more-jobs.html? nav $=5002$.

331. Greene, supra note 4.

332. See HYNE, supra note 7, at 425.

333. EPA USDW EVALUATION 2004, supra note 33, at 7-5. But see EPA USDW EVALUATION DRAFT 2011, supra note 75, at 39 (theorizing a link between fracking and groundwater contamination based on an investigation of one gas field in Wyoming).
} 
enterprise strictly liable for conducting an activity that is empirically safe.

Moreover, fracking is a natural and common use of the land. By the standards of a number of U.S. courts, it is natural to extract oil and gas from oil and gas lands. That fact assumes that extraction activities are matters of common usage, too, as that term is defined by an activity's vicinity. Finally, fracking employs local people at high rates, which is sufficiently valuable to offset a significant part of the activity's residual risk. Therefore, the section 520 factors probably weigh against finding that fracking is an abnormally dangerous activity. This conclusion does not foreclose the possibility of fraccidents. It is neither this Comment's argument, nor the Second Restatement's requirement, that fracking be deemed completely harmless. When fraccidents happen, courts should apply a negligence standard, and plaintiffs should seek res ipsa loquitur.

Courts have found negligence and res ipsa loquitur appealing alternatives to strict liability in natural gas pipeline and well shooting cases. $^{334}$ The key rationale in these cases is that accidents that do not tend to happen in the ordinary course of events absent some negligence should not be held to a strict liability standard. ${ }^{335}$ The foregoing analysis attempts to argue that this rationale holds true for fracking, as well.

Not only is res ipsa loquitur appropriate in fracking cases, it is also useful. Plaintiffs in accident cases often lack evidence of negligence, either because the accident destroyed $\mathrm{it}^{336}$ or because the cause was invisible or secret. ${ }^{337}$ The very purpose of res ipsa loquitur is to solve this problem. ${ }^{338}$

Further, res ipsa loquitur carries with it the advantages of negligence: tradition, safety promotion, loss distribution, and adjudicability. ${ }^{339}$

334. E.g., E. I. Du Pont de Nemours \& Co. v. Cudd, 176 F.2d 855, 857-58 (10th Cir. 1949) (noting that res ipsa loquitur would apply to this well shooting case but for the fact that defendant did not have exclusive control of the dangerous instrumentality); Mahowald v. Minn. Gas Co., 344 N.W.2d 856, 863 (Minn. 1984) (en banc) (applying res ipsa loquitur where plaintiff sought strict liability, and noting that the standard is appropriate in natural gas pipeline cases).

335. E.g., Mahowald, 344 N.W.2d at 863 (applying res ipsa loquitur where plaintiff sought strict liability, and noting that res ipsa loquitur is appropriate in natural gas pipeline cases).

336. See Jones, supra note 157, at 1735-36 (stating that res ipsa loquitur, like strict liability, is helpful to plaintiffs when evidence of negligence is destroyed).

337. Cudd, 176 F.2d at 857-58 (explaining that res ipsa loquitur is a remedy for plaintiffs who cannot know the secret cause of their injuries).

338. See Byrne v. Boadle, (1863) 159 Eng. Rep. 299, 2 H \& C 722 (establishing the res ipsa loquitur doctrine to make a plaintiff whole who could not prove that defendant was negligent when his barrel of flour fell from a window onto the plaintiff).

339. See supra Part II.B.3. 
Adjudicability is the most prescient. Fracking litigation is becoming increasingly widespread. Negligence is the better regime to adjudicate these claims efficiently because it avoids the obviously difficult and delicate fact-sensitive, risk-utility calculations over which this Comment labors. Finally, and importantly, negligence tempers the temptation that plaintiffs might feel to drag deep-pocketed oil and gas companies into court with less-than-meritorious claims.

This Comment's position is intended as a compromise. Res ipsa loquitur might not be entirely fair to defendants, but it is rebuttable. Res ipsa loquitur is a concession for plaintiffs, too, in cases in which strict liability otherwise might have been available. More broadly, res ipsa loquitur strikes a balance between enterprise liability and enterprise subsidy. The merits of res ipsa loquitur seem to speak for themselves. 